Argonne

ANL/ESD-21/18

\title{
Vehicle-cycle Inventory for Medium- and Heavy-duty Vehicles
}

Energy Systems Division 


\begin{abstract}
About Argonne National Laboratory
Argonne is a U.S. Department of Energy laboratory managed by UChicago Argonne, LLC under contract DE-AC02-06CH11357. The Laboratory's main facility is outside Chicago,

at 9700 South Cass Avenue, Lemont, Illinois 60439. For information about Argonne

and its pioneering science and technology programs, see www.anl.gov.
\end{abstract}

\title{
DOCUMENT AVAILABILITY
}

Online Access: U.S. Department of Energy (DOE) reports produced after 1991 and a growing number of pre-1991 documents are available free at OSTI.GOV (http://www.osti.gov/),

a service of the US Dept. of Energy's Office of Scientific and Technical Information.

Reports not in digital format may be purchased by the public from the National Technical Information Service (NTIS):

U.S. Department of Commerce

National Technical Information Service

5301 Shawnee Road

Alexandria, VA 22312

www.ntis.gov

Phone: (800) 553-NTIS (6847) or (703) 605-6000

Fax: (703) 605-6900

Email: orders@ntis.gov

Reports not in digital format are available to DOE and DOE contractors from the Office of Scientific and Technical Information (OSTI):

U.S. Department of Energy

Office of Scientific and Technical Information

P.O. Box 62

Oak Ridge, TN 37831-0062

www.osti.gov

Phone: (865) 576-8401

Fax: (865) 576-5728

Email: reports@osti.gov

\section{Disclaimer}

This report was prepared as an account of work sponsored by an agency of the United States Government. Neither the United States Government nor any agency thereof, nor UChicago Argonne, LLC, nor any of their employees or officers, makes any warranty, express or implied, or assumes any legal liability or responsibility for the accuracy, completeness, or usefulness of any information, apparatus, product, or process disclosed, or represents that its use would not infringe privately owned rights. Reference herein to any specific commercial product, process, or service by trade name, trademark, manufacturer, or otherwise, does not necessarily constitute or imply its endorsement, recommendation, or favoring by the United States Government or any agency thereof. The views and opinions of document authors expressed herein do not necessarily state or reflect those of the United States Government or any agency thereof, Argonne National Laboratory, or UChicago Argonne, LLC. 
ANL/ESD-21/18

\section{Vehicle-cycle Inventory for Medium- and Heavy-duty Vehicles}

by

Rakesh Krishnamoorthy lyer, Jarod C. Kelly, and Amgad Elgowainy

Energy Systems Division, Argonne National Laboratory

November 2021 



\section{CONTENTS}

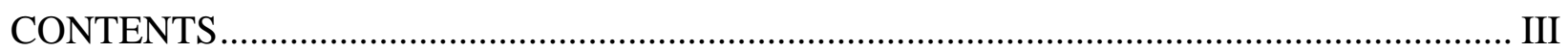

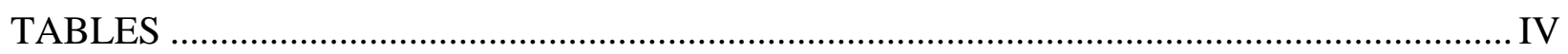

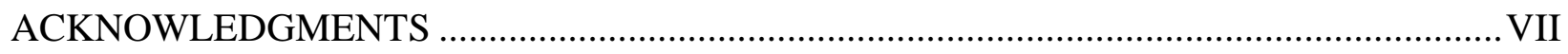

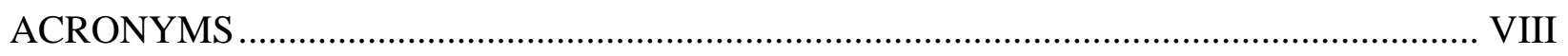

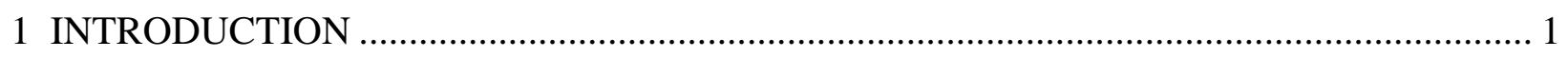

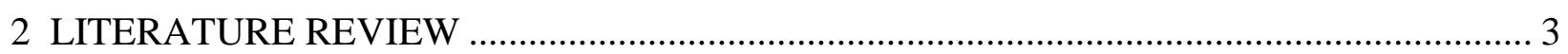

3 MODELING APPROACH AND VEHICLE SPECIFICATIONS ………............................ 5

3.1 Modeling Approach.................................................................................................. 5

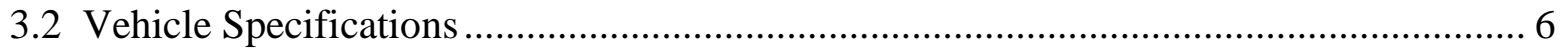

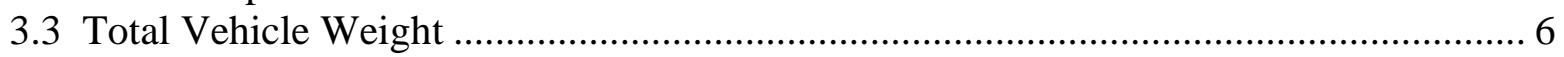

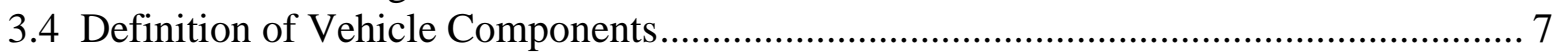

3.5 Vehicle Components: Material Composition and Weight............................................... 14

3.6 Fuel-cell Components and Batteries: Sizing, Weight, and Material Composition.......... 36

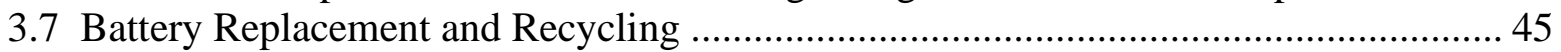

3.8 Fuel Stack Replacement ........................................................................................... 45

3.9 Replacements of Components: Tire, Fluids, Fuel Stacks, and Others ............................ 45

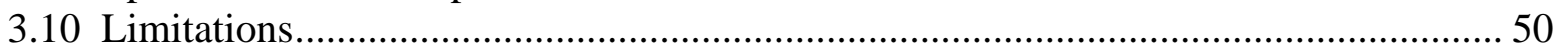

4 VEHICLE ASSEMBLY, DISPOSAL, AND RECYCLING ………………………….......... 51

5 GREET2 MODEL STRUCTURE EXPANSION FOR MHDVS …........................................ 52

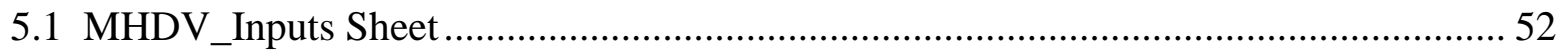

5.2 MHDV_Mat_Parameters Sheet.................................................................................... 53

5.3 Class 6 PnD Trucks, Class 8 Day-cab Trucks, and Class 8 Sleeper-cab Trucks

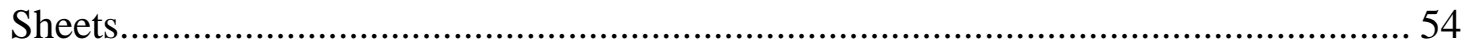

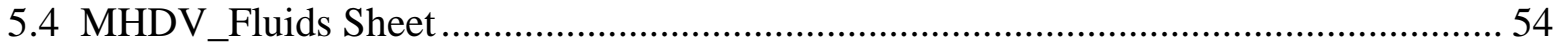

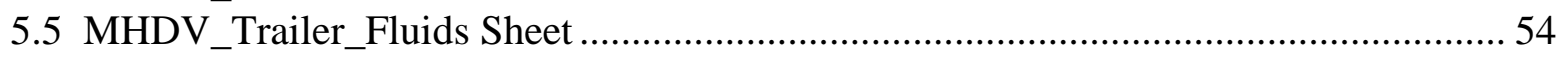

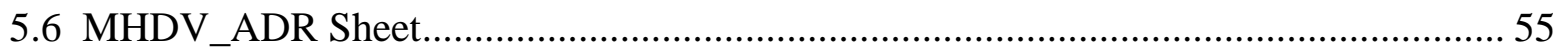

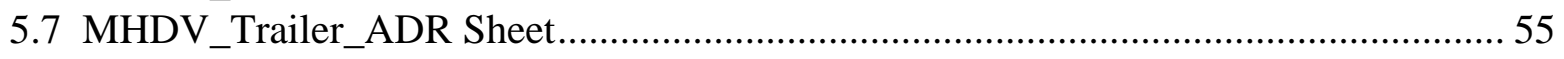

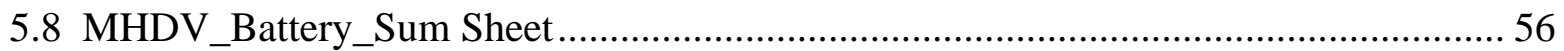

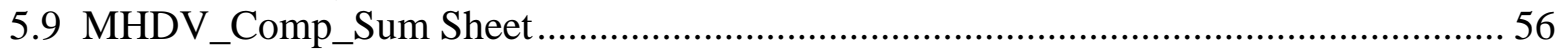

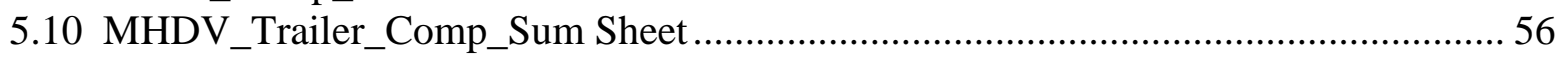

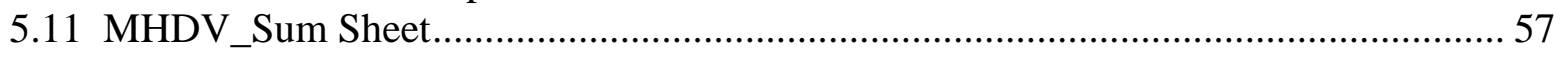

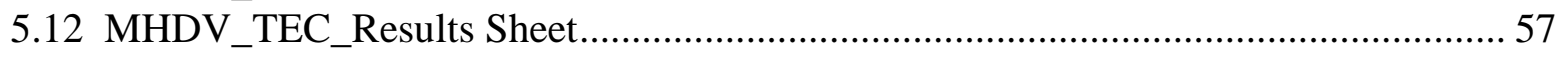

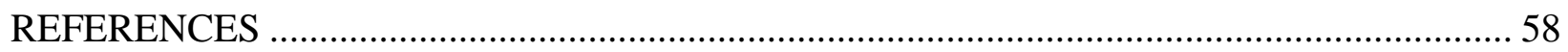




\section{TABLES}

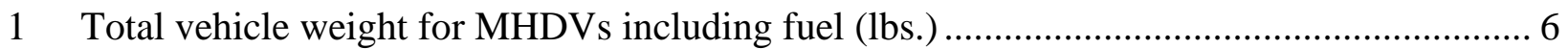

2 Component systems/categories included in GREET 2 for MHDVs ....................................... 7

3 Component systems used here and in Autonomie.......................................................... 8

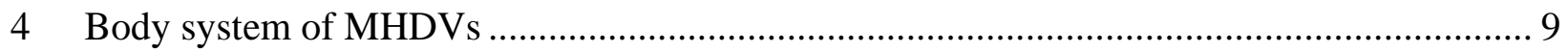

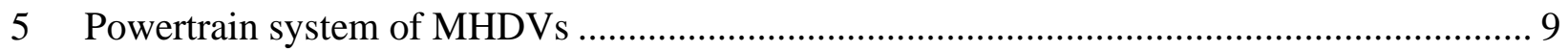

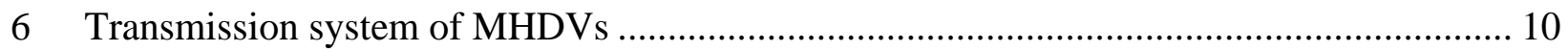

$7 \quad$ Chassis system of MHDVs.......................................................................................... 10

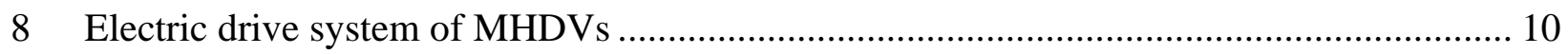

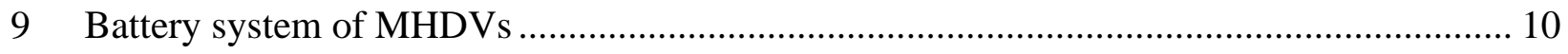

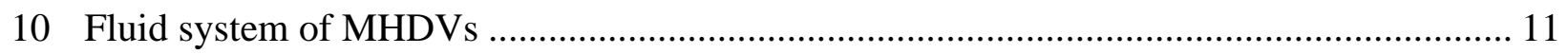

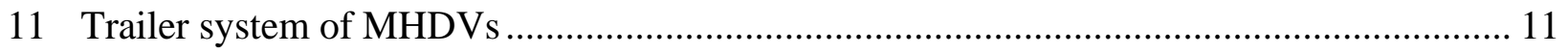

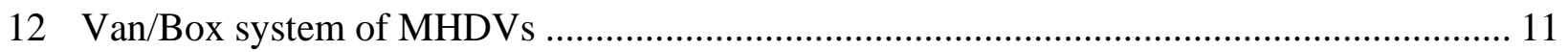

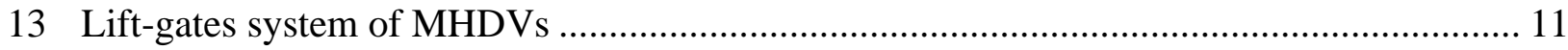

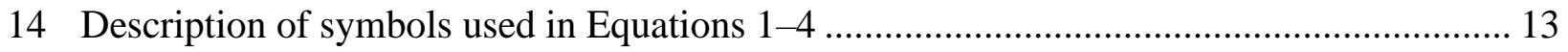

15 Data sources for MHDV component systems: Weight and material composition................. 15

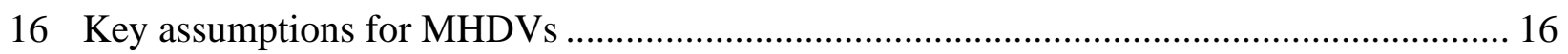

17 Weights for component systems, their important subsystems, and overall MHDV:

Class 6 PnD truck (lbs.)

18 Weights for component systems, their important subsystems, and overall MHDV:

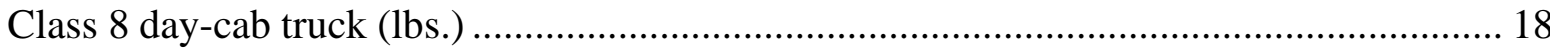

19 Weights for component systems, their important subsystems, and overall MHDV:

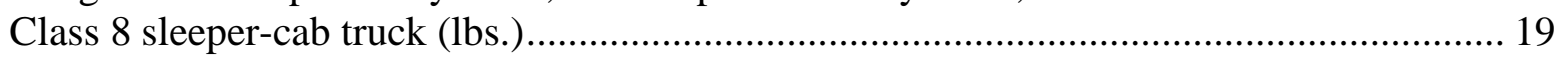

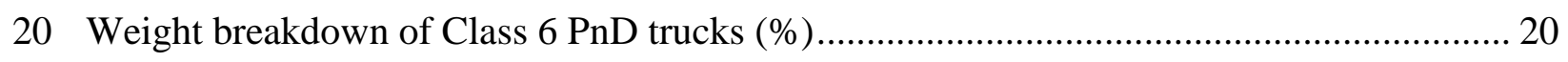

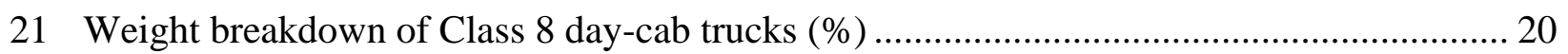

22 Weight breakdown of Class 8 sleeper-cab trucks (\%) ......................................................... 20 


\section{TABLES (CONT.)}

23 Material composition of component systems and subsystems in Class 6 PnD trucks ......... 21

24 Material composition of component systems and subsystems in Class 8 day-cab trucks..... 25

25 Material composition of component systems/subsystems in Class 8 sleeper-cab trucks ...... 29

26 Material composition of Class $6 \mathrm{PnD}$ trucks (aggregated over all component

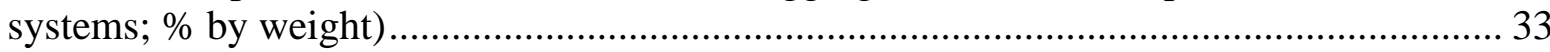

27 Material composition of Class 8 day-cab trucks (aggregated over all component

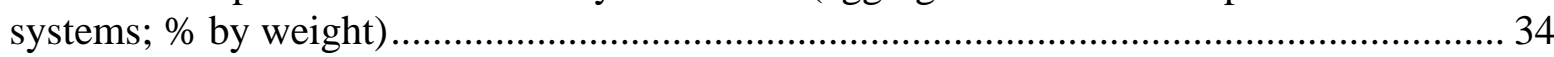

28 Material composition of Class 8 sleeper-cab trucks (aggregated over all component systems; $\%$ by weight).....

29 Net fuel-cell stack power values (in kW) for different vehicles for both Autonomie and SA 36

30 Total weight of fuel-cell stack system (lbs.) for MHDVs for both Autonomie and SA ....... 36

31 Material composition and weight of 700-bar and 350-bar fuel-cell onboard storage systems for all MHDVs

32 Number of hydrogen tanks and overall hydrogen amount stored in MHDVs as per SA...... 37

33 Battery power values (in kW) for HEV and FCV MHDVs, taken from Autonomie........... 38

34 Battery energy values (in kWh) for EV MHDVs, taken from Autonomie ......................... 38

35 Specific power and energy values of Li-ion batteries for different MHDVs ..................... 38

36 Material composition of Li-ion batteries in Class 6 PnD trucks (HEVs) (\%).................... 39

37 Material composition of Li-ion batteries in Class 6 PnD trucks (EVs) (\%)..................... 39

38 Material composition of Li-ion batteries in Class 6 PnD trucks (FCVs) (\%) ................... 40

39 Material composition of Li-ion batteries in Class 8 day-cab trucks (HEVs) (\%) ................ 40

40 Material composition of Li-ion batteries in Class 8 day-cab trucks (EVs) (\%) ................. 41

41 Material composition of Li-ion batteries in Class 8 day-cab trucks (FCVs) (\%)............... 41

42 Material composition of Li-ion batteries in Class 8 sleeper-cab trucks (HEVs) (\%)........... 42

43 Material composition of Li-ion batteries in Class 8 sleeper-cab trucks (EVs) (\%)............. 42 


\section{TABLES (CONT.)}

44 Material composition of Li-ion batteries in Class 8 sleeper-cab trucks (FCVs) (\%) ........... 43

45 Number of $\mathrm{Pb}$-acid batteries used for MHDVs with different propulsion technologies ....... 43

46 Material composition of $\mathrm{Pb}$-acid batteries in MHDVs.................................................. 44

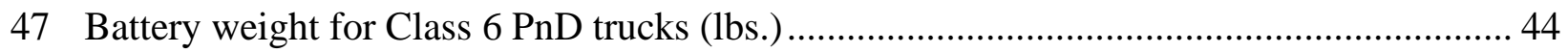

48 Battery weight for Class 8 day-cab trucks (lbs.) ....................................................... 44

49 Battery weight for Class 8 sleeper-cab trucks (lbs.) .................................................... 44

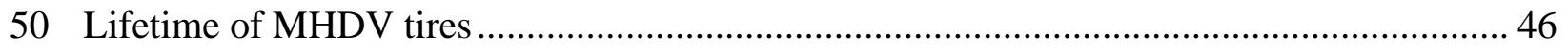

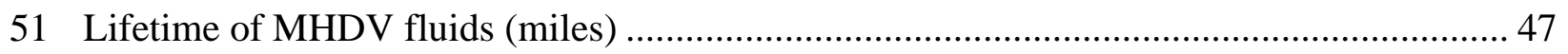

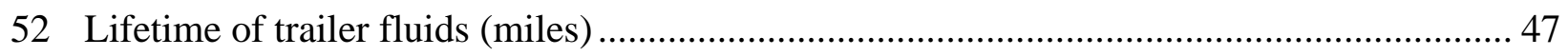

53 Major assumptions regarding all vehicle fluids (including trailer) ............................... 48

54 Amount of fluids used per use cycle in ICEV MHDVs ............................................. 48

55 Amount of fluids used per use cycle in HEV MHDVs .................................................. 49

56 Amount of fluids used per cycle in EV MHDVs .................................................. 49

57 Amount of fluids used per cycle in FCV MHDVs .................................................. 50

58 Lifetime of frequently replaced MHDV parts (years/miles) ....................................... 50

59 Energy use associated with vehicle and battery ADR processes ................................... 51 


\section{ACKNOWLEDGMENTS}

This activity was supported by the Vehicle Technologies Office and the Hydrogen and Fuel Cell Technology Office, Office of Energy Efficiency and Renewable Energy, U.S. Department of Energy (DOE) under Contract Number DE-AC02-06CH11357. The authors would like to thank Jacob Ward, Neha Rustagi, and David Howell of DOE for their guidance and support. They would also like to thank Ehsan Islam, Ram Vijayagopal, Shabbir Ahmed, and Aymeric Rousseau of Argonne National Laboratory and Brian James, Cassidy Houchins, and Jennie Huya-Kouadio of Strategic Analysis for their technical advisement. The views and opinions of the authors expressed herein do not necessarily state or reflect those of the U.S. Government or any agency thereof. Neither the U.S. Government nor any agency thereof, nor any of their employees, makes any warranty, expressed or implied, or assumes any legal liability or responsibility for the accuracy, completeness, or usefulness of any information, apparatus, product, or process disclosed, or represents that its use would not infringe privately owned rights. 


\section{ACRONYMS}

ADR

Argonne

BatPaC

BC

BMS

CAFE

CI

$\mathrm{CH}_{4}$

$\mathrm{CO}$

$\mathrm{CO}_{2}$

DOE

DoT

EPA

EV

FCV

GHG

GREET $^{\circledR}$

HDPE

HEV

HVAC

ICEV

lbs.

$\mathrm{kg}$

$\mathrm{kW}$

kWh

LCA

LDV

Li-ion

MHDV

mmBtu

$\mathrm{N}_{2} \mathrm{O}$
Assembly, disposal, and recycling

Argonne National Laboratory

Battery performance and cost

Black carbon

Battery management system

Corporate average fuel economy

Compression ignition

Methane

Carbon monoxide

Carbon dioxide

U.S. Department of Energy

U.S. Department of Transportation

U.S. Environmental Protection Agency

Electric vehicle

Fuel-cell (electric) vehicle

Greenhouse gas

Greenhouse gas, $\underline{R}$ egulated Emissions, and Energy $\underline{\text { Use in }}$ Transportation)

High-density polyethylene

Hybrid electric vehicle

Heating, ventilation, air conditioning

Internal combustion engine vehicle

Pounds

Kilogram

Kilowatt

Kilowatt hour

Life-cycle analysis

Light-duty vehicles

Lithium-ion

Medium- and heavy-duty vehicle

1 million British thermal unit

Nitrous oxide 


$\begin{array}{ll}\text { NMC } & \text { Nickel-manganese-cobalt } \\ \text { NOx } & \text { Nitrogen oxide } \\ \text { OC } & \text { Organic carbon } \\ \text { OEM } & \text { Original equipment manufacturers } \\ & \\ \mathrm{Pb}_{-} \text {acid } & \text { Lead-acid } \\ \mathrm{PM}_{2.5} \text { or } \mathrm{PM}_{10} & \text { Particulate matter } \\ \mathrm{PnD} & \text { Pickup and delivery } \\ \mathrm{PE} & \text { Polyethylene } \\ \mathrm{PET} & \text { Polyethylene terephthalate } \\ \mathrm{PFSA} & \text { Perfluoro sulfonic acid } \\ \mathrm{PP} & \text { Polypropylene } \\ \mathrm{PPS} & \text { Polyphenylene sulfide } \\ \mathrm{PTFE} & \text { Polytetrafluoroethylene } \\ \mathrm{PVDF} & \text { Polyvinylidene fluoride } \\ & \\ \mathrm{SA} & \text { Strategic analysis } \\ \mathrm{SO} & \text { Sulfur dioxide } \\ \mathrm{SO} \times & \text { Oxides of sulfur } \\ & \\ \text { VOCs } & \text { Volatile organic compounds } \\ \text { W/kg } & \text { Watt per kilogram } \\ \text { Wh/kg } & \text { Watt-hour per kilogram } \\ \text { wt.\% } & \text { Percentage by weight } \\ \text { WTW } & \text { Well-to-wheel }\end{array}$


This page intentionally left blank. 


\section{INTRODUCTION}

The United States has witnessed multiple attempts to improve fuel economy and reduce pollutant emissions in the transportation sector, guided chiefly via technological interventions by original equipment manufacturers (OEMs) and by specific policies of the U.S. Federal Government, like Corporate Average Fuel Economy (CAFE) norms (Burnham et al., 2006; U.S. DoT, 2013). These efforts have resulted in the growing adoption of alternatives to conventional materials, fuels, and vehicle propulsion technologies across various transportation modes, while also helping to lower global pollution (greenhouse gas, or GHG, emissions). Yet, a holistic evaluation of the ecofriendliness of these alternatives, particularly their energy use and emissions, merits detailed focus on their entire life-cycle, and thereby, on the life-cycle of associated transport modes. This is vital since alternative fuels and materials can differ vastly in energy sources and production methods employed for their processing vis-à-vis their existing counterparts - and this difference causes significant variation in their respective upstream emissions.

Over the last three decades, the Energy Systems Division at Argonne National Laboratory has undertaken the aforementioned task through life-cycle analysis (LCAs) of lightduty vehicles (LDVs), inclusive of both transportation fuels and vehicle technologies (Burnham, 2012; Burnham et al., 2006). Argonne's GREET ${ }^{\circledR}$ (Greenhouse gas, Regulated Emissions, and Energy Use in Transportation) model is both a product of and a tool for these analyses (Argonne National Laboratory, 2020). GREET ${ }^{\circledR}$ has been used to determine and analyze energy and emission impacts of different energy sources over their entire life-cycles [i.e., fuelcycle or well-to-wheel (WTW)]. Further, the model has expanded to encompass extraction, processing, production, and refining of prominent materials in desired forms, including metals, plastics, and composites. This has enabled researchers to use GREET ${ }^{\circledR}$ for LCAs of numerous energy sources and for advanced technologies across multiple sources, including but not confined to the transport sector.

Apart from LDVs, a key contributor to total energy consumption and emissions emanating from the transportation sector is freight transport, especially its road-based aspect (U.S. DOE, 2021; U.S. EPA, 2021), despite freight trucks constituting a small share of on-road vehicles (Davis \& Boundy, 2021). Hence, Argonne has identified the need to conduct LCA for on-road freight transport. GREET ${ }^{\circledR}$ already has the data that has been used to conduct WTW analysis of medium- and heavy-duty vehicles (MHDVs) (Argonne National Laboratory, 2020). However, it does not have the associated vehicle material burdens needed for cradle-to-grave analysis of MHDVs. This is a key requirement, as unlike LDVs, MHDVs require substantially more materials across different components, including for van/boxes and heavy-duty trailers, to ensure safe and reliable housing and transport of heavy goods. Also, MHDVs have considerably lower fuel economy than LDVs (Davis \& Boundy, 2021), leading to significant fuel use and emissions for them. Together, these factors increase the energy use and emissions of MHDVs over LDVs during their life-cycle stages, whether it be manufacturing of materials and components, component assembly and vehicle production, vehicle operation, or the recycling/disposal of vehicle components. 
Over the past decade, MHDVs have seen an increasing interest in alternative fuels and propulsion technologies, akin to LDVs (Burke \& Sinha, 2020; Forrest et al., 2020;

Kluschke et al., 2019). Researchers have investigated the replacement of diesel powertrains with alternative technologies, including hybridization, battery electric, and fuel-cell MHDVs

(Cunanan et al., 2021; Kluschke et al., 2019). There has also been an effort to shift away from conventional diesel toward other fuels, such as compressed natural gas, biofuels, and e-fuels (Bicer \& Dincer, 2018; Kluschke et al., 2019; Osorio-Tejada et al., 2017). At the same time, there has been a growing focus on improving powertrain efficiency of diesel trucks, developing novel after-treatment technologies to meet increasingly stringent emission norms, and lightweighting MHDVs to increase their fuel economy (Joshi, 2020; Kluschke et al., 2019; Rodríguez et al., 2017). Together, these trends have led to the incorporation of newer materials and components in MHDVs, with considerable variation in their energy and emission effects over their previously used counterparts.

The aforementioned trends and observations necessitate a thorough investigation of energy use and emissions of MHDVs over their entire life-cycle — encompassing major powertrain technologies, key materials, and aspects critical to this sector - to determine their overall environmental performance. This need is addressed here in this report through the description of a vehicle-cycle model that has been developed for MHDVs in GREET ${ }^{\circledR}$. Apart from providing energy and emission impacts of vehicle technologies and fuels, the model enables researchers to modify input assumptions and obtain energy use and emissions for userdefined MHDV types, MHDV material composition, and the nature of the fuel used (diesel, electric, etc.). The model also allows researchers to modify input assumptions related to upstream emissions of fuels (e.g., grid mix for electricity used in battery electric MHDVs, etc.) and assess their effects on MHDV energy use and emissions.

The rest of this document is organized as follows. Section 2 presents a brief literature review of the previously conducted studies. Section 3 provides a description of our modeling approach, specifications of MHDVs considered in this study, and a discussion on the processes and corresponding data inputs for MHDV component production. Section 4 provides a brief description of vehicle assembly, and end-of-life (recycling/disposal of their components). Finally, Section 5 presents the model structure used for MHDVs in the updated GREET ${ }^{\circledR}$ model and is followed by the references used in this study. 


\section{LITERATURE REVIEW}

While fewer LCAs have been conducted for MHDVs compared to LDVs, a number of MHDV LCAs have been undertaken over the last decade (Machado et al., 2021;

Sen et al., 2017). However, these studies have focused primarily on WTW analysis of fuels used for MHDVs (i.e., fuel-cycle analysis). This is because their main goal is to determine the environmental benefits (reduction in GHG and local pollutant emissions) of switching from conventional diesel to alternative fuels, such as natural gas, biofuels, electricity, and hydrogen. Among the remaining studies, some focus on the vehicle-cycle of buses (Sen et al., 2017). In contrast, only a few studies analyze the vehicle-cycle of freight-based MHDVs due to the dearth of inventory data for these vehicles in literature. These studies are discussed below in detail to provide the context and the need for the present work.

A vehicle-cycle analysis of MHDVs by Gaines et al. (1998) was conducted more than two decades ago. This study represents an early attempt to construct a detailed inventory for MHDVs towards conducting their process-based LCA. At the time of their study, the authors analyzed both the then-existing and advanced versions of Class 8 tractor-trailer trucks based on diesel (petroleum and Fischer-Tropsch) and liquefied natural gas. In their study, they highlight the dominance of iron, steel, and wrought aluminum in the material composition of these trucks while also discussing possibilities for MHDV lightweighting that could be achieved via use of aluminum and magnesium. Further, Gaines et al. (1998) conduct LCA of all the chosen Class 8 MHDVs and highlight the modest contributions from the vehicle-cycle to overall MHDV energy use and GHG emissions due to the predominant role of the fuel-cycle stage (vehicle operation, and fuel production and distribution). However, they also show the significant effect of the vehicle-cycle on four MHDV pollutant emissions on life-cycle basis: particulate matter $\left(\mathrm{PM}_{10}\right)$, oxides of sulfur ( $\mathrm{SO}$ ), volatile organic compounds (VOC), and methane $\left(\mathrm{CH}_{4}\right)$. Yet, given the significant passage of time since the publication of this report and the substantial efforts undertaken by OEMs since then to lightweight MHDVs, the inventory here cannot be considered to represent the modern-day MHDVs and thus needs updating.

Four studies (Sen et al., 2017; Zhao et al., 2016; Zhao \& Tatari, 2017; Zhou et al., 2017) constitute another set of literature on the vehicle-cycle of MHDVs. All these studies encompass the vehicle-cycle of MHDVs for different types of vehicles: Class 6 medium-duty trucks (Zhou et al., 2017), refuse collection trucks (Zhao \& Tatari, 2017), Class 8 heavy-duty trucks (Sen et al., 2017), and Class 4 trucks (Zhao et al., 2016). Along with the variation in the types of vehicles, two common themes emerge from these studies: their comparison of battery electric and diesel trucks, and the use of an economic input/output LCA approach to calculate the vehicle-cycle energy use and emissions. Overall, these studies highlight the benefits of truck electrification over conventional diesel trucks and the low influence of vehicle and battery manufacturing to the overall MHDV life-cycle energy use and emissions. However, the use of an input/output LCA approach negates the need to develop a detailed life-cycle inventory of MHDVs, thus leading to the lack of a recent inventory for their vehicle-cycles. This makes it difficult to assess if the impacts of vehicle production are indeed as low or negligible, as indicated in these four studies. 
The most recent work on the vehicle-cycle of MHDVs was conducted by Wolff et al. (2020) for multiple types of trucks to precisely address this gap on the lack of detailed inventory. However, due to the lack of sufficient literature on this subject, Wolff et al. (2020) used a number of references for weight and material composition of different MHDV component systems, including frame rails and cabs, chassis, and wheels and tires. They also scaled up the weight of several components (such as engines) by using the weight of the corresponding/analogous components in LDVs due to the paucity of publicly available data for these components. This makes it difficult to ensure that only MHDVs of similar performance across different powertrains (e.g., diesel, electric, and fuel-cell trucks) are being compared.

In sum, this review highlights the gap of a detailed MHDV vehicle-cycle inventory, which is essential to analyze its environmental impact for different powertrains and use these results to evaluate their overall life-cycle performance. The subsequent chapters focus on steps followed to create such an inventory as well as the final inventory developed from this exercise. 


\section{MODELING APPROACH AND VEHICLE SPECIFICATIONS}

\subsection{Modeling Approach}

The modeling approach used previously for LDVs in GREET ${ }^{\circledR}$ (Burnham, 2012; Burnham et al., 2006) has been extended to MHDVs here. Broadly, two energy cycles are considered to assess MHDV energy use and emissions: vehicle-cycle and fuel-cycle. The vehicle-cycle encompasses vehicle extraction, processing, and fabrication; component production (from materials) and their assembly to manufacture trucks; and end-of-life (recycling/disposal) of truck components. The fuel-cycle consists of production, storage, and distribution of primary energy and fuel, along with vehicle operation (fuel use for driving). Since MHDV energy use and emissions during the fuel-cycle are already established in GREET ${ }^{\circledR}$ (Argonne National Laboratory, 2020), these are directly used in this study, with the rest of this report focusing on vehicle-cycle modeling.

Like for LDVs, all the primary and secondary energy forms used in processes comprising the different vehicle-cycle stages are converted to final primary energy usage and emissions to provide a life-cycle perspective. For emissions, three GHGs $\left(\mathrm{CO}_{2}, \mathrm{CH}_{4}\right.$, and $\left.\mathrm{N}_{2} \mathrm{O}\right)$ and eight pollutants (VOCs, $\mathrm{CO}, \mathrm{NO}_{\mathrm{X}}, \mathrm{SO}_{2}, \mathrm{PM}_{10}, \mathrm{PM}_{2.5}, \mathrm{BC}$, and $\mathrm{OC}$ ) are computed based on in-built fuel and process characterization factors in GREET ${ }^{\circledR}$ (Argonne National Laboratory, 2020). Both emissions (total and urban) and water consumption are calculated for all vehicle-cycle related processes. All background calculations for LCA, derive from the existing GREET ${ }^{\circledR}$ model, that are well established and documented (Argonne National Laboratory, 2020).

The focus of this study is on determining the amount of each material used in MHDVs over their lifetime. For this, weights of prominent MHDV component systems are multiplied with their respective material composition, while accounting for the replacement of individual parts within these systems during the MHDV lifetime. Component systems considered here include: (a) systems that are common with the GREET ${ }^{\circledR}$ model for LDVs, such as body, chassis, powertrain, transmission, batteries, electric drive components (such as motor, electronic controller, and generator), fuel-cell hydrogen tank storage systems or fuel-cell onboard storage, and fluids; and (b) additional freight-specific systems that are used only in MHDVs, such as van/box, trailer, and lift-gates. Based on the materials used in these systems, the vehicle-cycle model (GREET2) calculates energy consumption and emissions across all its constituent processes. These effects, calculated for different component systems, are segregated, and grouped into five component categories: vehicle components, batteries, fluids, trailers, and the combined processes of truck assembly, painting, disposal, and recycling (ADR). Note that energy use and emissions for fluids and ADR processes employed for trailers are considered within the trailers category itself.

For most component systems in the vehicle-cycle, their definition for MHDVs is similar to that for LDVs in GREET ${ }^{\circledR}$ (Burnham, 2012; Burnham et al., 2006). Freight trucks employ additional fluids compared to those required for LDVs, prominent among which are lubricant oils (used for axle, driveshaft, inter-axle shaft, and wheel-ends) and coolant cleaners (used along 
with engine/powertrain coolant). Hence, the fluids group in this work expands beyond that for LDVs to include these additional fluids/lubricants.

\subsection{Vehicle Specifications}

Three MHDV options are considered in this study: a Class 6 pickup-and-delivery (PnD) truck, a Class 8 regional day-cab truck, and a Class 8 long-haul sleeper-cab truck. In the GREET1 Excel model, these are respectively referred to as follows: MHD vocational vehicle (Class 6 PnD truck), combination short-haul truck (Class 8 day-cab truck), and combination long-haul truck (Class 8 sleeper-cab truck). Three propulsion technologies are evaluated for these options: an internal combustion engine vehicle (ICEV) that uses a compression-ignition (CI) diesel engine; a battery electric vehicle (EV); and a fuel-cell electric vehicle (FCV) with hybrid configuration. In addition, for the Class 6 PnD truck, this study also includes a fourth propulsion technology in the form of a grid-independent hybrid electric vehicle (HEV) that is based on a CI diesel engine as primary source.

\subsection{Total Vehicle Weight}

Table 1 shows the total vehicle weights for all MHDVs and propulsion technologies that are considered in this study (excluding fuel). These weights correspond to the values provided for corresponding MHDVs in Autonomie simulations (Argonne National Laboratory, 2021).

Table 1 Total vehicle weight for MHDVs including fuel (lbs.)

\begin{tabular}{|c|c|c|c|c|}
\hline MHDV type & ICEV & HEV & EV & FCV \\
\hline Class 6 PnD & 16,984 & 17,120 & 19,177 & 16,654 \\
\hline Class 8 day-cab & 16,631 & 16,897 & 23,721 & 17,457 \\
\hline Class 8 sleeper-cab & 18,216 & 18,481 & 32,017 & 21,337 \\
\hline
\end{tabular}

For each of the chosen MHDVs, total vehicle weight is disaggregated into four of the five above-mentioned component categories: vehicle components, batteries, fluids, and trailers. Among these, vehicle components consist of ten key subsystems: truck body, chassis, transmission, powertrain, generator, traction motor, electronic controller, van/box, lift-gates, and fuel-cell onboard storage (or hydrogen tank storage system for fuel-cell trucks). Not every propulsion technology uses all of these components. For instance, while the ICEV employs only truck body, chassis, powertrain, and transmission, the HEV is a parallel hybrid truck that uses motor, electronic controller, and engine (diesel engine as primary source). Similarly, Class 6 PnD trucks use a van/box attached to the chassis, while Class 8 trucks use trailers that can be attached and detached from the chassis using a fifth-wheel. It is for this reason that the van/box is included within the vehicle components category, while trailers are considered a separate category (included in "Others" within the GREET.Net model). Lastly, an electric motor powers 
both EV and FCV MHDVs, with the FCV being a hybrid truck model that uses a fuel-cell and battery as its primary and secondary energy sources, respectively.

Like LDVs, freight trucks also employ batteries for vehicle startup and accessory loads. Across all MHDVs and propulsion technologies, the base battery is lead-acid ( $\mathrm{Pb}$-acid). Apart from this, a lithium-ion (Li-ion) battery is provided as a traction battery in $\mathrm{HEV}, \mathrm{EV}$, and FCV MHDVs. Conversely, as stated earlier, fluids used in MHDVs expand beyond those used in LDVs to include engine oil, lubricant oils (used for steer and drive axles, inter-axle shaft, driveshaft, and wheel-ends at both axles), power steering fluid/oil, engine/powertrain coolant with coolant cleaner, transmission fluid, brake fluid, windshield fluid, and adhesives. Trailers consist of several parts that are categorized into three groups in this study: trailer body, chassis (includes trailer axle with brakes, suspensions, wheels, and tires), and auxiliary components or parts. Trailers also include fluids that are used specifically for their chassis (lubricant oils for the trailer axle and its wheel-ends) as well as ADR processes employed for trailer manufacturing.

\subsection{Definition of Vehicle Components}

As in LDVs, freight trucks use multiple parts that are aggregated into different component systems (Table 2), which is in line with the prior GREET ${ }^{\circledR}$ work on LDVs (Burnham, 2012; Burnham et al., 2006). Apart from the total vehicle weight, it is the weight (and material composition) of these systems that is relevant in evaluating and comparing the environmental outcomes of MHDV vehicle-cycles.

Table 2 Component systems/categories included in GREET2 for MHDVs

\begin{tabular}{|c|c|c|c|c|}
\hline Component System & ICEV & HEV & EV & FCV \\
\hline Truck Body & $\checkmark$ & $\checkmark$ & $\checkmark$ & $\checkmark$ \\
\hline Chassis & $\checkmark$ & $\checkmark$ & $\checkmark$ & $\checkmark$ \\
\hline Transmission & $\checkmark$ & $\checkmark$ & $\checkmark$ & $\checkmark$ \\
\hline Powertrain & $\checkmark$ & $\checkmark$ & $\checkmark$ & $\checkmark$ \\
\hline Traction Motor & & $\checkmark$ & $\checkmark$ & $\checkmark$ \\
\hline Generator & & $\checkmark$ & & \\
\hline Electronic Controller & & & $\checkmark$ & $\checkmark$ \\
\hline Fuel-cell Onboard Storage & $\checkmark$ & $\checkmark$ & $\checkmark$ & $\checkmark$ \\
\hline Batteries & $\checkmark$ & $\checkmark$ & $\checkmark$ & $\checkmark$ \\
\hline Fluids (excluding fuel) & $\checkmark$ & $\checkmark$ & $\checkmark$ & $\checkmark$ \\
\hline Trailers & & & &
\end{tabular}

In this context, we use Autonomie - a simulation tool for vehicles developed by researchers at Argonne (Argonne National Laboratory, 2021; Islam et al., 2021). Autonomie calculates various characteristics of vehicles across all weight classes (Class 1-8) via use of several parameters, including powertrain/engine maps, different performance inputs, and drive cycles. These characteristics include, but are not confined to, total vehicle weight and weight breakup of vehicle component systems, vehicular fuel economies, and power/energy/sizing needs 
for batteries across different vehicles (by powertrain and weight class). This provides an opportunity to use these values to inform vehicle component sizing here and, thereby, compare MHDVs of equivalent performance across different powertrains (i.e., like-for-like comparison). However, the component systems used in Autonomie and their definitions differ from those used in this analysis (Table 3). To resolve this divergence, a combination of bottom-up and top-down approaches were used to determine the weight of all the component systems chosen in this work (Table 2).

Table 3 Component systems used here and in Autonomie

\begin{tabular}{|c|c|}
\hline Systems: Autonomie & Systems: This Study \\
\hline & $\begin{array}{c}\text { Chassis (includes steer and drive axles, brakes, suspensions, } \\
\text { driveshaft, inter-axle shaft, wheels, and tires) } \\
\text { Truck body } \\
\text { Box/Van/Trailer } \\
\text { Chassis }\end{array}$ \\
& $\begin{array}{c}\text { Lift-gates and Vehicle fluids } \\
\text { Powertrain (After-treatment technology) }\end{array}$ \\
\hline Powertrain (ICEV/HEV) & Powertrain (ICEV/HEV engine) \\
\hline Transmission & Transmission (clutch, gearbox, and final drive) \\
\hline Generator & Electric drive components (generator) \\
\hline Motor & Traction motor and electronic controller \\
\hline Batteries & Batteries (Pb-acid and Li-ion) \\
\hline Fuel Tank & Powertrain (fuel tank) \\
\hline Hydrogen Tank & Fuel-cell onboard storage \\
\hline Fuel Cell & Powertrain (fuel-cell stacks) \\
\hline
\end{tabular}

The need for a bottom-up approach arises from two reasons. First, it is vital in determining the material composition for each component system, and thereby, for all MHDVs across different propulsion technologies. This is relevant since the amount of material use affects energy use and emissions of trucks, as highlighted earlier. Also, the bottom-up approach ensures that for all the component systems in MHDVs (Table 2), their constituent subsystems and individual parts are included within vehicle-cycle calculations. This is important as GREET ${ }^{\circledR}$ users are not presented with any of the individual subsystems or parts, but only the information about final component systems (Table 2).

To implement this bottom-up approach, Tables 4-13 provide the definitions of all the component systems considered in this study. For most systems, their definitions extend from Argonne's earlier work on LDVs (Argonne National Laboratory, 2020; Burnham, 2012; Burnham et al., 2006) due to similarity in constituents across both transport modes. Components that are employed only in MHDVs (van/box/trailer and lift-gates) are defined separately in terms of their constituent subsystems and individual parts (Tables 11-13). Additionally, the truck body includes sleeper-related components for Class 8 sleeper-cab trucks (Table 4), while chassis includes a fifth-wheel used to detach and attach trailers to Class 8 trucks (both day-cab and sleeper-cab trucks; Table 7). On similar lines, the fluid system in MHDVs encapsulates the expanded set of fluids mentioned earlier (Table 10). Based on these definitions, the weight of each component system was derived using bottom-up calculations. 
Table 4 Body system

\begin{tabular}{|c|l|}
\hline Subsystems & \multicolumn{1}{|c|}{ Description of Individual Parts } \\
\hline Cab-in-white & $\begin{array}{l}\text { Primary MHDV structure, i.e., a single-body assembly to which the other } \\
\text { major components are attached }\end{array}$ \\
\hline $\begin{array}{c}\text { Body Panels and } \\
\text { Fairings }\end{array}$ & $\begin{array}{l}\text { Closure and hang-on panels, including hood, roof, decklid, doors, quarter } \\
\text { panels, and fenders, as well as fairings }\end{array}$ \\
\hline Front/Rear Bumpers & Impact bars, energy absorbers, and mounting hardware \\
\hline Glass & Front windshield, and windows (door, side, and sleeper) \\
\hline Lighting & $\begin{array}{l}\text { Exterior: Head lamps, fog lamps, turn signals, side markers, front top } \\
\text { markers, and rear light assemblies } \\
\text { Interior: Wiring and controls for interior lighting, instrumentation, and } \\
\text { power accessories }\end{array}$ \\
\hline $\begin{array}{c}\text { Heating, Ventilation, } \\
\text { Air Conditioning } \\
\text { (HVAC) Module }\end{array}$ & $\begin{array}{l}\text { Air flow system, heating system, and air conditioning system (includes a } \\
\text { condenser, fan, heater, ducting, and controls) }\end{array}$ \\
\hline $\begin{array}{c}\text { Seating and Restraint } \\
\text { System }\end{array}$ & $\begin{array}{l}\text { Seat tracks, seat frames, foam, trim, restraints, anchors, head restraints, arm } \\
\text { rests, seat belts, tensioners, clips, air bags, and sensor assemblies }\end{array}$ \\
\hline Door Module & $\begin{array}{l}\text { Door insulation, trim assemblies, speaker grills, and switch panels and } \\
\text { handles (door panels are part of body panels) }\end{array}$ \\
\hline Instrument Panel & $\begin{array}{l}\text { Panel structure, knee bolsters and brackets, instrument cluster (including } \\
\text { switches), exterior surface, console storage, glove box panels, glove box } \\
\text { assembly and exterior, and top cover }\end{array}$ \\
\hline Sleeper-cab & $\begin{array}{l}\text { Emergency brake cover, switch panels, ash trays, cup holders, headliner } \\
\text { assemblies, overhead console assemblies, assist handles, overhead storage, } \\
\text { pillar trim, sun visors, carpet/rubber, padding, insulation, and accessory mats }\end{array}$ \\
\hline Body Hardware & $\begin{array}{l}\text { Meant for Class 8 sleeper-cab trucks, consisting of sitting and sleeping area } \\
\text { with space for other amenities (microwave, refrigerator, etc.) }\end{array}$ \\
\hline Miscellaneous body components \\
\hline
\end{tabular}

Table 5 Powertrain system

\begin{tabular}{|c|l|}
\hline Subsystems & \multicolumn{1}{|c|}{ Description of Individual Parts } \\
\hline Engine Unit & $\begin{array}{l}\text { Engine block, cylinder heads, shafts, fuel injection, engine air system, ignition } \\
\text { system, manifolds, alternator, containers and pumps for the lubrication system, } \\
\text { gaskets, and seals }\end{array}$ \\
\hline Fuel-cell Stack & $\begin{array}{l}\text { Membrane electrode assembly, bipolar plates, gaskets, current collector, } \\
\text { insulator, outer wrap, motor and motor controller, humidifier, coolant reservoir } \\
\text { and pumps, radiator, sensors, valves, and tie bolts }\end{array}$ \\
\hline $\begin{array}{c}\text { Engine Fuel Storage } \\
\text { System }\end{array}$ & $\begin{array}{l}\text { Fuel tank, tank mounting straps, tank shield, insulation, filling piping, and } \\
\text { supply piping }\end{array}$ \\
\hline $\begin{array}{c}\text { Powertrain Thermal } \\
\text { System }\end{array}$ & Water pump, radiator, and fan \\
\hline Exhaust System & Catalytic converter, muffler, heat shields, and exhaust piping \\
\hline $\begin{array}{c}\text { Powertrain Electrical } \\
\text { System }\end{array}$ & Control wiring, sensors, switches, and processors \\
\hline $\begin{array}{c}\text { Emission Control } \\
\text { Electronics }\end{array}$ & Sensors, processors, and engine emission feedback equipment \\
\hline
\end{tabular}


Table 6 Transmission system

\begin{tabular}{|c|l|}
\hline Subsystems & \multicolumn{1}{c|}{ Description of Individual Parts } \\
\hline Transmission Unit & $\begin{array}{l}\text { Clutch, gear box, final drive, and controls } \\
\text { Use of automated manual transmission system }\end{array}$ \\
\hline
\end{tabular}

Table 7 Chassis system

\begin{tabular}{|c|l|}
\hline Subsystems & \multicolumn{1}{|c|}{ Description of Individual Parts } \\
\hline Cradle & $\begin{array}{l}\text { Frame assembly, front rails and cross-members, and cab and body brackets } \\
\text { (the cradle bolts to cab-in-white and supports the mounting of engine or } \\
\text { fuel-cell) }\end{array}$ \\
\hline $\begin{array}{c}\text { Driveshaft/Axle/ } \\
\text { Inter-axle Shaft }\end{array}$ & $\begin{array}{l}\text { Propeller shaft that connects gearbox to the differential } \\
\text { Half shaft that connects wheels to the differential } \\
\text { Shafts that connect front and rear parts of a tandem drive axle }\end{array}$ \\
\hline Axles & Steer (single) and drive (tandem) axles \\
\hline Differential & $\begin{array}{l}\text { A gear set that transmits energy from driveshaft to axles and allows for each } \\
\text { of the driving wheels to rotate at different speeds while supplying them with } \\
\text { an equal amount of torque }\end{array}$ \\
\hline Suspensions & $\begin{array}{l}\text { Upper and lower shock brackets, shock absorbers, springs, steering knuckle, } \\
\text { and stabilizer shaft }\end{array}$ \\
\hline Braking System & Hub, disc, rotor, splash shield, and calipers \\
\hline Wheels and Tires & Steer and drive axle wheels and tires \\
\hline Fifth-wheel & Fifth-wheel (used in Class 8 trucks) \\
\hline Auxiliary & $\begin{array}{l}\text { Steering wheel, column, joints, linkages, bushes, housings, and hydraulic- } \\
\text { assist equipment }\end{array}$ \\
\hline
\end{tabular}

Table 8 Electric drive system

\begin{tabular}{|c|l|}
\hline Subsystems & \multicolumn{1}{c|}{ Description of Individual Parts } \\
\hline Generator & $\begin{array}{l}\text { Power converter that takes mechanical energy from the engine and produces } \\
\text { electrical energy to recharge batteries and power the electric motor for series } \\
\text { HEV (not used in this study, as the HEV is a parallel HEV MHDV) }\end{array}$ \\
\hline Traction Motor & Electric motor used to drive the wheels \\
\hline Electronic Controller & $\begin{array}{l}\text { Power controller/phase inverter system that converts power between the } \\
\text { batteries and motor/generators for electric drive vehicles }\end{array}$ \\
\hline $\begin{array}{c}\text { Fuel-cell Auxiliary } \\
\text { Components (fuel-cell } \\
\text { onboard storage) }\end{array}$ & $\begin{array}{l}\text { Compressed hydrogen tank system, tank liner and boss, dome protection, in- } \\
\text { tank valve, regulator, housing and support, and other balance of plant } \\
\text { (systems for water supply, air supply, cooling, and piping) }\end{array}$ \\
\hline
\end{tabular}

Table 9 Battery system

\begin{tabular}{|c|l|}
\hline Subsystems & \multicolumn{1}{c|}{ Description of Individual Parts } \\
\hline ICEV & Pb-acid battery to handle startup and accessory load \\
\hline HEV, EV, and FCV & $\begin{array}{l}\text { Pb-acid battery to handle mainly startup load } \\
\text { Li-ion battery for use in electric drive system }\end{array}$ \\
\hline
\end{tabular}


Table 10 Fluid system

\begin{tabular}{|c|l|}
\hline Subsystems & \multicolumn{1}{c|}{ Description of Individual Parts } \\
\hline ICEV and HEV & $\begin{array}{l}\text { Engine oil, engine/powertrain coolant with coolant cleaner, brake fluid, } \\
\text { windshield fluid, transmission fluid, power steering fluid, lubricant oils, and } \\
\text { adhesives }\end{array}$ \\
\hline EV and FCV & $\begin{array}{l}\text { Powertrain coolant with coolant cleaner, power steering fluid, brake fluid, } \\
\text { transmission fluid, windshield fluid, lubricant oils, adhesives }\end{array}$ \\
\hline
\end{tabular}

Table 11 Trailer system

\begin{tabular}{|c|l|}
\hline Subsystems & \multicolumn{1}{c|}{ Description of Individual Parts } \\
\hline Body & Front, sides, floor, and roof of trailers \\
\hline Chassis & Axles, suspensions, brakes, and shafts \\
\hline Auxiliary & $\begin{array}{l}\text { Trailer components not covered in body and chassis, such as landing gear, } \\
\text { trailer bumpers, lighting, and mudflaps }\end{array}$ \\
\hline
\end{tabular}

Table 12 Van/Box system

\begin{tabular}{|c|c|}
\hline Subsystems & \multicolumn{1}{c|}{ Description of Individual Parts } \\
\hline Body & Front, sides, floor, and roof of van/box, along with auxiliary parts \\
\hline
\end{tabular}

Table 13 Lift-gates system

\begin{tabular}{|c|l|}
\hline Subsystems & \multicolumn{1}{c|}{ Description of Individual Parts } \\
\hline Lift-gates & $\begin{array}{l}\text { Gates used for loading/unloading of goods, along with their hydraulic } \\
\text { systems and other constituent parts }\end{array}$ \\
\hline
\end{tabular}

A top-down approach was subsequently employed to use Autonomie weight values (Argonne National Laboratory, 2021; Islam et al., 2021) to scaleup the weights obtained via bottom-up calculations. This was needed as any comparative life-cycle evaluation of MHDVs across different propulsion technologies requires them to exhibit equivalent performance (such as on vehicle towing, for instance). Since Autonomie has already conducted this analysis and sized various component systems appropriately for this purpose (such as for engines, fuel-cell stacks, and transmission), these weights are combined with material composition (obtained using bottom-up approach) to determine the final MHDV material breakup. However, exceptions exist to this method for certain component systems within the vehicle components category and for other component categories (like batteries and fluids). These exceptions are discussed in the relevant subsections, with this subsection focusing solely on the vehicle components category.

For common component systems between this study and Autonomie (e.g., transmission; Table 3), the value of the system weight provided in Autonomie is used directly. However, when these systems have different definitions across both sources, a hybrid scale-up approach is used to combine system weights from Autonomie with weights obtained via bottom-up approach. 
To better understand this scale-up, consider the example of chassis as defined in Autonomie with its definition in this study (Tables 3 and 7). In Autonomie, the chassis definition includes frame rails and cross-members, steer and drive axles, suspensions and brakes for these axles, driveshaft and inter-axle shaft, truck body, box/van/trailer, lift-gates, wheels, vehicle fluids, electronic accessory, and exhaust after-treatment. In contrast, this study incorporates frame rails and cross-members, axles, suspensions, brakes, driveshaft, inter-axle shaft, wheels, and tires in the definition of chassis, while accounting for truck body (includes electronic accessories), vehicle fluids, lift-gates, and exhaust after-treatment (in powertrain) as separate systems (Tables 3-13). Hence, the scaling-up approach for chassis is a three-step process to obtain the weight of individual component systems (Table 3) to reach Autonomie's vehicle weight (based on Equations 1-4, as explained below).

$$
\begin{aligned}
& W_{\text {Chassis, } A \_d e f \_B} \\
& =W_{\text {cross_members_frame_rails } B}+W_{\text {steer_axle }_{-} B}+W_{\text {drive_axle }_{-} B} \\
& +W_{\text {suspensions } B}+W_{\text {truck_body_B }}+W_{\text {shafts } B}^{-}+W_{\text {vbt_B }}+W_{\text {lift_gate } B} \\
& +W_{\text {after_treatment_B }} \ldots . . \\
& W S(\%)_{\text {component_A_def }}=\frac{W_{\text {component } B}}{W_{\text {Chassis, } A_{-} \text {def }_{-} B}} \cdots \\
& W_{\text {Chassis }, A_{-} \text {def }}=W_{\text {Overall_chassis,A_def }_{-}}-\left(W_{\text {vehicle_fluids } B_{-}}+W_{\text {wheels }_{-} B}\right) \ldots . . \\
& W_{\text {component } A_{\_} \text {def }}=W S(\%)_{\text {component }_{\perp} B} \times W_{\text {Chassis, } A_{-} \text {def }} \cdots . .
\end{aligned}
$$

Consider any one of the chosen MHDVs (e.g., Class 6 ICEV MHDV). In the first step, the bottom-up weights of all individual components/constituent systems (excluding vehicle fluids and wheels) that constitute Autonomie's definition of the chassis (Table 3) are summed up (here, $A_{-} d e f$ is Autonomie-defined and $B$ is bottom-up) to obtain the bottom-up weight of chassis as per Autonomie's definition (Equation 1). Wheels and vehicle fluids are excluded here as these elements cannot be reasonably scaled, as will be done with other components. Next, the bottomup weight of all component systems is used to calculate their respective weight shares in the final bottom-up Autonomie-defined chassis weight (Equation 2). For instance, the weight share of truck body is obtained by dividing the bottom-up truck body weight $\left(W_{\text {truck_body_B }}\right)$ by the summed bottom-up Autonomie-defined chassis weight $\left(W_{\text {Chassis,A_def_B }}\right)$. Next, the combined bottom-up weight of wheels and vehicle fluids is subtracted from the overall Autonomiesupplied chassis weight (Equation 3). Subsequently, the weight shares obtained using Equation 2 are used to scale-up individual component systems, such that their final sum matches with the Autonomie-defined chassis weight (minus the vehicle fluids and wheels; Equation 4). A detailed description of the symbols used in Equations 1-4 is provided in Table 14. 
Table 14 Description of symbols used in Equations 1-4

\begin{tabular}{|c|c|}
\hline Symbols & Description \\
\hline$W_{\text {cross_members_frame_rails_B }}$ & Bottom-up weight of cross-members and frame rails \\
\hline$W_{\text {Steer_axle_B }}$ & Bottom-up weight of steer axle \\
\hline$W_{\text {drive_axle_B }}$ & Bottom-up weight of drive axle \\
\hline$W_{\text {Suspensions_B }}$ & Bottom-up weight of suspensions and brakes for all axles \\
\hline$W_{\text {truck_body_B }}$ & Bottom-up weight of truck body \\
\hline$W_{\text {Shafts_B }}$ & Bottom-up weight of driveshaft and inter-axle shaft \\
\hline$W_{v b t \_B}$ & Bottom-up weight of van/box/trailer \\
\hline$W_{\text {lift_gate_B }}$ & Bottom-up weight of lift-gate system \\
\hline$W_{\text {after_treatment_B }}$ & Bottom-up weight of exhaust after-treatment system \\
\hline$W_{\text {Chassis,A_def_B }}$ & $\begin{array}{l}\text { Bottom-up weight of chassis, where the chassis is defined as per } \\
\text { Autonomie (Table 3) }\end{array}$ \\
\hline$W_{\text {component_B }}$ & $\begin{array}{l}\text { Bottom-up weight of component, where the component can be cross- } \\
\text { members + frame rails, drive axle, steer axle, truck body, suspensions } \\
\text { and brakes, driveshaft and inter-axle shaft, van/box/trailer, lift-gate, or } \\
\text { exhaust after-treatment }\end{array}$ \\
\hline$W S(\%)_{\text {component_B }}$ & $\begin{array}{l}\text { Bottom-up weight share of component, where the component can be } \\
\text { cross-members + frame rails, drive axle, steer axle, truck body, } \\
\text { suspensions and brakes, driveshaft and inter-axle shaft, van/box/trailer, } \\
\text { lift-gate, or exhaust after-treatment }\end{array}$ \\
\hline$W_{\text {vehicle_fluids_B }}$ & Bottom-up weight of vehicle fluids \\
\hline$W_{\text {wheels_B }}$ & Bottom-up weight of wheels \\
\hline$W_{\text {Overall_chassis,A_def }}$ & Overall weight of chassis in Autonomie \\
\hline$W_{\text {Chassis,A_def }}$ & $\begin{array}{l}\text { Weight of chassis (minus vehicle fluids and wheels) as per Autonomie, } \\
\text { using the chassis definition from Autonomie }\end{array}$ \\
\hline$W_{\text {component, } A_{-} \text {def }}$ & $\begin{array}{l}\text { Scaled-up weight of component to Autonomie truck weight, where the } \\
\text { component can be cross-members + frame rails, drive axle, steer axle, } \\
\text { truck body, suspensions and brakes, driveshaft and inter-axle shaft, } \\
\text { van/box/trailer, lift-gate, or exhaust after-treatment }\end{array}$ \\
\hline
\end{tabular}

Apart from chassis, a simpler scale-up approach is used for the powertrain, transmission, and electric-drive components (traction motor and electronic controller, as generator is not used in any vehicle). For the powertrain, engine weight from the bottom-up approach is scaled up to the sum of engine, alternator/generator, and mechanical accessory weights in Autonomie for all ICEV and HEV MHDVs (Table 5). Similarly, the transmission weight from bottom-up approach is scaled up to the sum of the weight of transmission subsystem in Autonomie (clutch, gearbox, final drives, and truck coupling; Table 6). Lastly, like for the chassis, the sum of traction motor and electronic controller weights from the bottom-up approach is scaled up to the motor weight for EV MHDVs in Autonomie (Table 8), while maintaining a similar ratio of weight distribution between these two components as in the bottom-up approach (analogous to the three-step process used for chassis). Fuel tank weight is scaled up directly from Autonomie for this study. Conversely, like for wheels and vehicle fluids, the weight of tires obtained via the bottom-up approach is used directly in this study (within chassis) for the chosen MHDV, assuming it to be the same for MHDVs in both Autonomie and bottom-up versions. 
Unlike the above-mentioned components, Autonomie is not used directly to determine the weight of batteries and fuel-cell parts (fuel-cell stacks as powertrain, and fuel-cell auxiliary systems or hydrogen tank storage systems; both are used in fuel-cell MHDVs). Instead, a mixture of alternative sources is used along with Autonomie-based parameters to determine the weight of these two components, while using their same definitions as used in Autonomie (see Tables 3-13). More information is provided in Sections 3.6 and 3.7.

\subsection{Vehicle Components: Material Composition and Weight}

Apart from weight, a fair comparison of MHDVs across various propulsion technologies requires detailed information on their material composition along with an appropriate sizing of their major constituent subsystems and individual parts. However, the literature review undertaken for this study did not identify any prior studies on dismantling and/or sizing subsystems/parts to estimate MHDV material composition, making it difficult to use this research to evaluate their life-cycle environmental output.

To overcome this, a bottom-up approach (discussed in Section 3.4) was used to collect the bottom-up weight and material composition data for MHDV component systems by compiling and aggregating the weight and composition of their individual parts and subsystems. A variety of data sources were used for this process, including: (a) technical literature (academic journals, conference papers, and academic and technical reports); (b) company literature (studies, websites, catalogs, etc.) from manufacturers and sellers of individual parts, subsystems, and/or component systems used in present-day versions of chosen MHDVs; (c) the existing GREET ${ }^{\circledR}$ model for LDVs (Argonne National Laboratory, 2020; Burnham, 2012; Burnham et al., 2006); (d) personal communication with Strategic Analysis (SA) regarding fuel-cell stacks and auxiliary components (fuel-cell onboard storage) (James et al., 2021); and (e) other assumptions, when necessary.

For component systems classified under the vehicle components category, the material composition of individual parts/subsystems were aggregated to derive the overall composition of each component system, and subsequently, for the entire truck for all MHDVs. The same approach was used for the trailers category as well, while the material composition of MHDV vehicle fluids was extended from the GREET ${ }^{\circledR}$ LDV model (Argonne National Laboratory, 2020; Burnham, 2012; Burnham et al., 2006). Appropriate modifications were made for the additional fluids that are used only in MHDVs.

Regarding batteries, the material composition of $\mathrm{Pb}$-acid batteries was extended from the GREET $^{\circledR}$ LDV model (Argonne National Laboratory, 2020; Burnham, 2012; Burnham et al., 2006). On the other hand, for Li-ion batteries, data was obtained via Battery Performance and Cost (BatPaC) 4.0 model by inputting MHDV-specific battery parameters (voltage, energy, current, and operating time) that are consistent with those used in the Autonomie model. Lastly, for fuel-cell components (fuel-cell stack and onboard storage), the material composition was obtained via suitable modification of details provided by SA (James et al., 2021). More information is given in Section 3.6. 
A detailed list of data sources used to obtain material constituents and weights of individual parts and subsystems for each component system is provided in Table 15. In addition, for each system, the weight share of various subsystems is calculated and used for subsequent analysis.

Apart from material composition, a few critical assumptions are made in this study to conduct like-for-like comparison of MHDVs spanning various propulsion technologies. The material composition and weight of truck body and chassis are assumed to be the same across all propulsion technologies for a single MHDV (be it Class $6 \mathrm{PnD}$, Class 8 day-cab, or Class 8 sleeper-cab truck). On similar lines, the material composition and weight of van/box (for Class 6 trucks) and trailer (for Class 8 trucks) are also considered to be the same, regardless of the propulsion technology used. However, these assumptions cannot be extended to other components for all the MHDVs due to variation in their incorporation and sizing with changes in propulsion technology (ICEV, HEV, EV, or FCV). Another key assumption is for trailers, whose operational lifetime is treated to be the same as that of Class 8 truck tractor. Other key assumptions for various component systems and/or their subsystems are provided in Table 16.

Table 15 Data sources for MHDV component systems: Weight and material composition

\begin{tabular}{|c|c|c|}
\hline $\begin{array}{l}\text { Component } \\
\text { Systems }\end{array}$ & Sub-components & Key References \\
\hline Truck Body & $\begin{array}{l}\text { Interior and } \\
\text { Exterior Parts }\end{array}$ & $\begin{array}{l}\text { (75 Chrome Shop, 2021; Auto Zone Inc., 2021; Big Rig } \\
\text { World, 2021; Big Truck Hoods, 2021; Cardone, 2019; } \\
\text { Daimler Trucks North America LLC, 2021; Fleet Truck } \\
\text { Parts, 2021; Pradeep et al., 2017; Ragatz \& Thornton, } \\
\text { 2016; Truck iD, 2021) }\end{array}$ \\
\hline \multirow{5}{*}{ Chassis } & $\begin{array}{l}\text { Cross-members and } \\
\text { Frame Rails }\end{array}$ & $\begin{array}{l}\text { (Big Rig World, 2021; Navistar Inc., 2021; RitchieSpecs, } \\
\text { 2018; Volvo Group, 2021) }\end{array}$ \\
\hline & $\begin{array}{l}\text { Axles, Suspension, } \\
\text { and Brakes }\end{array}$ & $\begin{array}{l}\text { (Dana Ltd., 2021; Dana Ltd. \& Dana Spicer, 2021; Dana } \\
\text { Spicer, 2019; FinditParts Inc., 2021; SAF-Holland Group, } \\
\text { 2021; W. W. Grainger Inc., 2021) }\end{array}$ \\
\hline & Wheels and Tires & $\begin{array}{l}\text { (Buy Truck Wheels, 2021; The Goodyear Tire \& Rubber } \\
\text { Company, 2021) }\end{array}$ \\
\hline & Fifth-wheel & (FinditParts Inc., 2021; SAF-Holland Group, 2021) \\
\hline & $\begin{array}{c}\text { Differential and } \\
\text { Electrical System }\end{array}$ & $\begin{array}{l}\text { (Dana Ltd., 2021; Dana Ltd. \& Dana Spicer, 2021; Dana } \\
\text { Spicer, 2019) }\end{array}$ \\
\hline \multirow{3}{*}{ Powertrain } & Engines & (Cummins, 2021) \\
\hline & Fuel Cell Stacks & (James et al., 2021) \\
\hline & Others & (4 State Trucks, 2021) \\
\hline Transmission & & $\begin{array}{l}\text { (Drivetrain America, 2021; Eaton, 2014; W. W. Grainger } \\
\text { Inc., 2021) }\end{array}$ \\
\hline \multirow{3}{*}{$\begin{array}{l}\text { Electric-drive } \\
\text { Components }\end{array}$} & Traction Motor & \multirow{3}{*}{ (Dana Ltd. \& Dana Spicer, 2021; Dana Spicer, 2019) } \\
\hline & Generator & \\
\hline & Electronic Controller & \\
\hline $\begin{array}{c}\text { Fuel cell } \\
\text { Auxiliary } \\
\text { Components }\end{array}$ & Hydrogen Tanks & $\begin{array}{l}\text { (Argonne National Laboratory, 2021; Islam et al., 2021; } \\
\text { James et al., 2021) }\end{array}$ \\
\hline
\end{tabular}


Table 15 (Cont.)

\begin{tabular}{|c|l|l|}
\hline $\begin{array}{c}\text { Component } \\
\text { Systems }\end{array}$ & Sub-components & \multicolumn{1}{|c|}{ Key References } \\
\hline \multirow{2}{*}{ Van/Box/Trailer } & & (Chassis King, 2021; FinditParts Inc., 2021; Morgan \\
& & Truck Body, 2021; SAF-Holland Group, 2021; STI \\
& Holdings Inc., 2012, 2021; W. W. Grainger Inc., 2021) \\
\hline \multirow{2}{*}{ Batteries } & & (Argonne National Laboratory, 2018, 2021; Interstate \\
& Batteries, 2021; Islam et al., 2021) \\
\hline \multirow{2}{*}{ Fluids } & & (Auto Zone Inc., 2021; Cummins, 2021; Cummins \\
& & Filtration, 2021; Dana Ltd., 2021; Dana Ltd. \& Dana \\
& Spicer, 2021; Dana Spicer, 2019; Eaton, 2018) \\
\hline Lift-gates & (Woodbine Manufacturing Company Inc., 2018) \\
\hline
\end{tabular}

Table 16 Key assumptions for MHDVs

\begin{tabular}{|c|c|}
\hline Aspects & Assumptions and Underlying Reason \\
\hline Material Inventory & $\begin{array}{l}\text { - No inventory (energy use and emissions) considered for nichrome and } \\
\text { bronze, with their material composition assumed using literature: } \\
-\quad \text { Nichrome: } 80 \% \text { nickel }+20 \% \text { chromium } \\
-\quad \text { Bronze: } 88 \% \text { copper }+12 \% \text { tin } \\
\text { - No inventory (material use, energy use, and emissions) considered for } \\
\text { damask fiber, leather, latex, cotton paper, ceramic, wood, tin, niobium, } \\
\text { chromium, and titanium } \\
\text { - Inventory for brass considered to be the same as that for copper } \\
\text { - Inventory for magnet considered to be the same as that for iron } \\
\text { - Inventory for silica considered to be the same as that for sand } \\
\text { - Underlying reason: Lack of alternative data/inventory in current GREET }\end{array}$ \\
\hline $\begin{array}{c}\text { Material } \\
\text { Composition/Use }\end{array}$ & $\begin{array}{l}\text { - Amount of virgin and recycled share for different materials assumed to be } \\
\text { the same as that for LDVs in GREET } \\
\text { - Material composition of average plastic for MHDVs assumed to be the } \\
\text { same as that for LDVs in GREET }{ }^{\circledR} \\
\text { - Underlying reason: Lack of alternative data/inventory in literature }\end{array}$ \\
\hline Component Systems & $\begin{array}{l}\text { - Material composition of engine (including engine unit, powertrain thermal } \\
\text { and electrical systems, and emission control electronics) assumed to be the } \\
\text { same for both ICEV and HEV powertrains for any one type of MHDV } \\
\text { (Class } 6 \text { PnD or Class } 8 \text { day-cab/sleeper-cab) } \\
\text { - Material composition of transmission systems assumed to be the same for } \\
\text { all powertrains for any one type of MHDV } \\
\text { - Material composition of electric drive components (traction motor, } \\
\text { electronic controller, and generator) assumed to be the same as that for } \\
\text { these components in GREET }{ }^{\circledR} \text { LDVs } \\
\text { - Lift-gates assumed to be made entirely of steel due to lack of material } \\
\text { composition break-up in literature }\end{array}$ \\
\hline
\end{tabular}


Tables 17-19 provide the weight of all component systems (excluding batteries and fluids) and their major subsystems for the chosen MHDVs. While system weights are based on the scaled-up hybrid approach, subsystem weights are the product of their respective weight shares within the system (obtained via bottom-up approach) and the overall system weight (obtained from Autonomie or using Autonomie). Tables 20-22 provide the weight share of each component system, developed by calculating their respective weight by the sum of weight of all systems (i.e., the entire MHDV minus the combined weight of batteries, fluids, and fuel). Material composition of all constituent systems, and of the MHDV (as obtained via bottom-up approach), are provided in Tables 23-28.

Table 17 Weights for component systems, their important subsystems, and overall MHDV: Class 6 PnD truck (lbs.)

\begin{tabular}{|c|c|c|c|c|}
\hline Component System/Subsystem & ICEV & HEV & EV & FCV \\
\hline \multicolumn{5}{|l|}{ Truck Body } \\
\hline Body and Glass & 1,117 & 1,117 & 1,117 & 1,117 \\
\hline Interior & 1,002 & 1,002 & 1,002 & 1,002 \\
\hline Exterior & 288 & 288 & 288 & 288 \\
\hline \multicolumn{5}{|l|}{ Chassis } \\
\hline Steer Axle (includes brakes) & 759 & 759 & 759 & 759 \\
\hline Drive Axle (includes brakes and differential assembly) & 958 & 958 & 958 & 958 \\
\hline Shafts (driveshaft, axle, and inter-axle shaft) & 113 & 113 & 113 & 113 \\
\hline Suspensions (steer and drive axles) & 1,104 & 1,104 & 1,104 & 1,104 \\
\hline Wheels and Tires & 1,020 & 1,020 & 1,020 & 1,020 \\
\hline Cradle (frame rails, cross-members), Fifth-wheel, and Auxiliary & 2,207 & 2,207 & 2,207 & 2,207 \\
\hline \multicolumn{5}{|l|}{ Powertrain } \\
\hline $\begin{array}{c}\text { Engine Unit (inclusive of powertrain thermal and electrical system, } \\
\text { and emission control electronics) }\end{array}$ & 992 & 895 & 0 & 0 \\
\hline Fuel-cell Stack & 0 & 0 & 0 & 558 \\
\hline Engine Fuel Storage + Exhaust Systems & 430 & 430 & 0 & 0 \\
\hline \multicolumn{5}{|l|}{ Transmission } \\
\hline Clutch & 55 & 55 & 0 & 0 \\
\hline Gearbox & 366 & 364 & 154 & 154 \\
\hline Final Drive and Coupling & 66 & 66 & 44 & 55 \\
\hline \multicolumn{5}{|l|}{ Electric-drive Components } \\
\hline Traction Motor & 0 & 105 & 295 & 295 \\
\hline Generator & 0 & 0 & 0 & 0 \\
\hline Electronic Controller & 0 & 10 & 29 & 29 \\
\hline Fuel-cell Onboard Storage & 0 & 0 & 0 & 489 \\
\hline Van-box & 4,772 & 4,772 & 4,772 & 4,772 \\
\hline Lift-gates & 1,325 & 1,325 & 1,325 & 1,325 \\
\hline
\end{tabular}


Table 18 Weights for component systems, their important subsystems, and overall MHDV: Class 8 day-cab truck (lbs.)

\begin{tabular}{|c|c|c|c|c|}
\hline Component System/Subsystem & ICEV & HEV & $\mathbf{E V}$ & FCV \\
\hline \multicolumn{5}{|l|}{ Truck Body } \\
\hline Body and Glass & 1,258 & 1,258 & 1,258 & 1,258 \\
\hline Interior & 1,281 & 1,281 & 1,281 & 1,281 \\
\hline Exterior & 214 & 214 & 214 & 214 \\
\hline \multicolumn{5}{|l|}{ Chassis } \\
\hline Steer Axle (includes brakes) & 759 & 759 & 759 & 759 \\
\hline Drive Axle (includes brakes and differential assembly) & 958 & 958 & 958 & 958 \\
\hline Shafts (driveshaft, axle, and inter-axle shaft) & 113 & 113 & 113 & 113 \\
\hline Suspensions (steer and drive axles) & 1,104 & 1,104 & 1,104 & 1,104 \\
\hline Wheels and Tires & 1,020 & 1,020 & 1,020 & 1,020 \\
\hline Cradle (frame rails, cross-members), Fifth-wheel, and Auxiliary & 2,207 & 2,207 & 2,207 & 2,207 \\
\hline \multicolumn{5}{|l|}{ Powertrain } \\
\hline $\begin{array}{l}\text { Engine Unit (inclusive of powertrain thermal and electrical system, } \\
\text { and emission control electronics) }\end{array}$ & 2,610 & 2,582 & 0 & 0 \\
\hline Fuel-cell Stack & 0 & 0 & 0 & 1,532 \\
\hline Engine Fuel Storage + Exhaust Systems & 398 & 398 & 0 & 0 \\
\hline \multicolumn{5}{|l|}{ Transmission } \\
\hline Clutch & 55 & 55 & 0 & 0 \\
\hline Gearbox & 778 & 778 & 315 & 324 \\
\hline Final Drive and Coupling & 110 & 110 & 88 & 88 \\
\hline \multicolumn{5}{|l|}{ Electric-drive Components } \\
\hline Traction Motor & 0 & 183 & 626 & 642 \\
\hline Generator & 0 & 0 & 0 & 0 \\
\hline Electronic Controller & 0 & 19 & 66 & 68 \\
\hline Fuel-cell Onboard Storage & 0 & 0 & 0 & 2,209 \\
\hline \multicolumn{5}{|l|}{ Trailer } \\
\hline Trailer Body & 5,558 & 5,558 & 5,558 & 5,558 \\
\hline Trailer Chassis & 4,423 & 4,423 & 4,423 & 4,423 \\
\hline Trailer Auxiliary & 594 & 594 & 594 & 594 \\
\hline
\end{tabular}


Table 19 Weights for component systems, their important subsystems, and overall MHDV: Class 8 sleeper-cab truck (lbs.)

\begin{tabular}{|c|c|c|c|c|}
\hline Component System/Subsystem & ICEV & HEV & $\mathbf{E V}$ & FCV \\
\hline \multicolumn{5}{|l|}{ Truck Body } \\
\hline Body and Glass & 1,444 & 1,444 & 1,444 & 1,444 \\
\hline Interior & 1,559 & 1,559 & 1,559 & 1,559 \\
\hline Exterior & 343 & 343 & 343 & 343 \\
\hline \multicolumn{5}{|l|}{ Chassis } \\
\hline Steer Axle (includes brakes) & 759 & 759 & 759 & 759 \\
\hline Drive Axle (includes brakes and differential assembly) & 958 & 958 & 958 & 958 \\
\hline Shafts (driveshaft, axle, and inter-axle shaft) & 113 & 113 & 113 & 113 \\
\hline Suspensions (steer and drive axles) & 1,104 & 1,104 & 1,104 & 1,104 \\
\hline Wheels and Tires & 1,020 & 1,020 & 1,020 & 1,020 \\
\hline $\begin{array}{l}\text { Cradle (frame rails, cross-members), Fifth-wheel, and } \\
\text { Auxiliary }\end{array}$ & 2,207 & 2,207 & 2,207 & 2,207 \\
\hline \multicolumn{5}{|l|}{ Powertrain } \\
\hline $\begin{array}{l}\text { Engine Unit (inclusive of powertrain thermal and } \\
\text { electrical system, and emission control electronics) }\end{array}$ & 2,610 & 2,582 & 0 & 0 \\
\hline Fuel-cell Stack & 0 & 0 & 0 & 1,525 \\
\hline Engine Fuel Storage + Exhaust Systems & 411 & 411 & 0 & 0 \\
\hline \multicolumn{5}{|l|}{ Transmission } \\
\hline Clutch & 55 & 55 & 0 & 0 \\
\hline Gearbox & 778 & 778 & 315 & 322 \\
\hline Final Drive and Coupling & 110 & 110 & 88 & 88 \\
\hline \multicolumn{5}{|l|}{ Electric-drive Components } \\
\hline Traction Motor & 0 & 183 & 624 & 638 \\
\hline Generator & 0 & 0 & 0 & 0 \\
\hline Electronic Controller & 0 & 19 & 66 & 68 \\
\hline Fuel-cell Onboard Storage & 0 & 0 & 0 & 4,609 \\
\hline \multicolumn{5}{|l|}{ Trailer } \\
\hline Trailer Body & 5,974 & 5,974 & 5,974 & 5,974 \\
\hline Trailer Chassis & 4,652 & 4,652 & 4,652 & 4,652 \\
\hline Trailer Auxiliary & 638 & 638 & 638 & 638 \\
\hline
\end{tabular}


Table 20 Weight breakdown of Class 6 PnD trucks (\%)

\begin{tabular}{|c|c|c|c|c|}
\hline Component System & ICEV & HEV & EV & FCV \\
\hline Truck Body & 14.5 & 14.5 & 15.9 & 14.8 \\
\hline Powertrain & 8.6 & 8.0 & 0.0 & 3.4 \\
\hline Transmission & 2.9 & 2.9 & 1.3 & 1.3 \\
\hline Chassis & 37.2 & 37.1 & 40.6 & 37.9 \\
\hline Traction Motor & 0.0 & 0.6 & 1.9 & 1.8 \\
\hline Generator & 0.0 & 0.0 & 0.0 & 0.0 \\
\hline Electronic Controller & 0.0 & 0.1 & 0.2 & 0.2 \\
\hline Fuel-cell Onboard Storage & 0.0 & 0.0 & 0.0 & 3.0 \\
\hline Van/Box & 28.8 & 28.8 & 31.4 & 29.4 \\
\hline Lift-gates & 8.0 & 8.0 & 8.7 & 8.2 \\
\hline
\end{tabular}

Table 21 Weight breakdown of Class 8 day-cab trucks (\%)

\begin{tabular}{|c|c|c|c|c|}
\hline Component System & ICEV & HEV & EV & FCV \\
\hline Truck Body & 10.4 & 10.3 & 11.6 & 10.0 \\
\hline Powertrain & 11.3 & 11.2 & 0.0 & 5.6 \\
\hline Transmission & 3.6 & 3.5 & 1.7 & 1.5 \\
\hline Chassis & 34.9 & 34.7 & 39.1 & 33.8 \\
\hline Traction Motor & 0.0 & 0.7 & 2.6 & 2.3 \\
\hline Generator & 0.0 & 0.0 & 0.0 & 0.0 \\
\hline Controller or Inverter & 0.0 & 0.1 & 0.3 & 0.2 \\
\hline Fuel-cell Auxiliary Components & 0.0 & 0.0 & 0.0 & 8.0 \\
\hline Trailer & 39.8 & 39.6 & 44.6 & 38.5 \\
\hline
\end{tabular}

Table 22 Weight breakdown of Class 8 sleeper-cab trucks (\%)

\begin{tabular}{|c|c|c|c|c|}
\hline Component System & ICEV & HEV & EV & FCV \\
\hline Truck Body & 11.6 & 11.6 & 12.9 & 10.4 \\
\hline Powertrain & 10.5 & 10.3 & 0.0 & 4.8 \\
\hline Transmission & 3.3 & 3.3 & 1.6 & 1.3 \\
\hline Chassis & 35.4 & 35.2 & 39.3 & 31.8 \\
\hline Traction Motor & 0.0 & 0.6 & 2.4 & 2.0 \\
\hline Generator & 0.0 & 0.0 & 0.0 & 0.0 \\
\hline Controller or Inverter & 0.0 & 0.1 & 0.3 & 0.2 \\
\hline Fuel-cell Auxiliary Components & 0.0 & 0.0 & 0.0 & 14.4 \\
\hline Van/Box/Trailer & 39.2 & 38.9 & 43.5 & 35.2 \\
\hline
\end{tabular}


Table 23 Material composition of component systems and subsystems in Class 6 PnD trucks

\begin{tabular}{|c|c|}
\hline Component System/Subsystem & Material Composition \\
\hline \multicolumn{2}{|l|}{ Body (all powertrains) } \\
\hline Body and Glass & $\begin{array}{l}38 \% \text { glass fiber-reinforced plastic } \\
22 \% \text { steel } \\
20 \% \text { glass } \\
16 \% \text { wrought aluminum } \\
4 \% \text { plastic (average) }\end{array}$ \\
\hline Interior & $\begin{array}{l}61 \% \text { steel } \\
21 \% \text { plastic (average) } \\
8 \% \text { cast aluminum } \\
5 \% \text { rubber } \\
3 \% \text { leather } \\
1 \% \text { wrought aluminum } \\
\sim 1 \% \text { others (copper/brass, damask, latex, and cotton paper) }\end{array}$ \\
\hline Exterior and Auxiliary & $\begin{array}{l}38 \% \text { plastic } \\
30 \% \text { steel } \\
10 \% \text { rubber } \\
9 \% \text { cast aluminum } \\
8 \% \text { glass } \\
5 \% \text { copper/brass } \\
\sim 0 \% \text { wrought aluminum }\end{array}$ \\
\hline \multicolumn{2}{|l|}{ Chassis (all powertrains) } \\
\hline Tires (steer and drive) & $\begin{array}{l}66.7 \% \text { rubber } \\
33 \% \text { steel }\end{array}$ \\
\hline Wheels (steer and drive) & $100 \%$ aluminum \\
\hline Steer Axle (including brakes) & $\begin{array}{l}61 \% \text { steel } \\
39 \% \text { cast iron } \\
\sim 0 \% \text { others (cast and wrought aluminum, rubber, plastic, brass, copper, and magnet) }\end{array}$ \\
\hline $\begin{array}{l}\text { Drive Axle (including brakes and } \\
\text { differential assembly) }\end{array}$ & $\begin{array}{l}76 \% \text { steel } \\
23 \% \text { cast iron } \\
\sim 1 \% \text { others (cast aluminum. rubber, plastic, brass, and magnet) }\end{array}$ \\
\hline
\end{tabular}


Table 23 (Cont.)

\begin{tabular}{|c|c|}
\hline Component System/Subsystem & Material Composition \\
\hline \multicolumn{2}{|l|}{ Chassis (all powertrains) } \\
\hline Tires (steer and drive) & $\begin{array}{l}66.7 \% \text { rubber } \\
33 \% \text { steel }\end{array}$ \\
\hline Wheels (steer and drive) & $100 \%$ aluminum \\
\hline Steer Axle (including brakes) & $\begin{array}{l}61 \% \text { steel } \\
39 \% \text { cast iron } \\
\sim 0 \% \text { others (cast and wrought aluminum, rubber, plastic, brass, copper, and magnet) }\end{array}$ \\
\hline $\begin{array}{l}\text { Drive Axle (including brakes and } \\
\text { differential assembly) }\end{array}$ & $\begin{array}{l}76 \% \text { steel } \\
23 \% \text { cast iron } \\
\sim 1 \% \text { others (cast aluminum, rubber, plastic, brass, and magnet) }\end{array}$ \\
\hline Suspensions (drive and steer axles) & $\begin{array}{l}91 \% \text { steel } \\
3 \% \text { cast iron } \\
6 \% \text { rubber } \\
\sim 0 \% \text { plastic }\end{array}$ \\
\hline $\begin{array}{c}\text { Shafts (driveshaft, inter-axle shaft, } \\
\text { axle shaft) }\end{array}$ & $\begin{array}{l}95 \% \text { steel } \\
5 \% \text { cast iron } \\
\sim 0 \% \text { others (rubber, plastic, and grease) }\end{array}$ \\
\hline Cradle, Fifth-wheel, and Auxiliary & $100 \%$ steel \\
\hline \multicolumn{2}{|l|}{ Powertrain } \\
\hline $\begin{array}{c}\text { Engine Unit } \\
\text { (inclusive of powertrain thermal and } \\
\text { electrical system, and emission } \\
\text { control electronics; ICEV and HEV } \\
\text { powertrains) }\end{array}$ & $\begin{array}{l}53 \% \text { cast iron } \\
37 \% \text { steel } \\
6 \% \text { cast aluminum } \\
2 \% \text { wrought aluminum } \\
1 \% \text { plastic } \\
\sim 1 \% \text { others (stainless steel, rubber, nichrome, and others) }\end{array}$ \\
\hline
\end{tabular}


Table 23 (Cont.)

\begin{tabular}{|c|c|}
\hline Component System/Subsystem & Material Composition \\
\hline \multicolumn{2}{|l|}{ Powertrain } \\
\hline $\begin{array}{c}\text { Fuel-cell Stack } \\
\text { (FCV powertrain) }\end{array}$ & $\begin{array}{l}40 \% \text { stainless steel } \\
12 \% \text { polypropylene (PP) } \\
11 \% \text { steel } \\
8 \% \text { wrought aluminum } \\
7 \% \text { cast aluminum } \\
4 \% \text { average plastic } \\
3 \% \text { each of glass fiber-reinforced plastic, rubber, polyethylene terephthalate (PET), and copper/brass } \\
2 \% \text { plastic [polyphenylene sulfide (PPS) and other plastics] } \\
1.5 \% \text { carbon } \\
1 \% \text { each of carbon paper and perfluoro sulfonic acid (PFSA) } \\
0 \% \text { others [polytetrafluoroethylene (PTFE), nickel, iron, nylon, chromium, platinum, high-density } \\
\text { polyethylene (HDPE), molybdenum, glass, ceramic, niobium, titanium, cast iron, bronze, graphite, } \\
\text { fiberglass, nichrome, PFSA Nafion, and others] }\end{array}$ \\
\hline $\begin{array}{l}\text { Engine Fuel Storage + } \\
\text { Exhaust Systems } \\
\text { (ICEV and HEV powertrains) }\end{array}$ & $\begin{array}{l}33 \% \text { wrought aluminum } \\
24 \% \text { ceramic } \\
19 \% \text { plastic (average) } \\
14 \% \text { stainless steel } \\
10 \% \text { steel } \\
\sim 0 \% \text { others (rubber and platinum) } \\
\end{array}$ \\
\hline $\begin{array}{l}\text { Transmission } \\
\text { (all powertrains) }\end{array}$ & $\begin{array}{l}69 \% \text { steel } \\
24 \% \text { cast iron } \\
6 \% \text { cast aluminum } \\
\sim 1 \% \text { others (wrought aluminum, rubber, plastic, copper, brass, magnet, and grease) }\end{array}$ \\
\hline \multicolumn{2}{|c|}{ Electric-drive components (HEV, EV, and FCV powertrains) } \\
\hline Traction Motor and Generator & $\begin{array}{l}36 \% \text { steel } \\
36 \% \text { cast aluminum } \\
28 \% \text { copper and brass }\end{array}$ \\
\hline
\end{tabular}


Table 23 (Cont.)

\begin{tabular}{|c|l|}
\hline Component System/Subsystem & \\
\hline Electric-drive Components (HEV, EV, and FCV powertrains) \\
\hline & $5 \%$ steel \\
& $47 \%$ cast aluminum \\
\hline & $8 \%$ copper and brass \\
\hline & $4 \%$ rubber \\
& $24 \%$ average plastic \\
& $12 \%$ others \\
\hline & $73 \%$ carbon fiber-reinforced composite \\
& $13 \%$ stainless steel \\
& $6 \%$ wrought aluminum \\
& $3 \%$ each of HDPE and steel \\
& $2 \%$ PP \\
& $\sim 0 \%$ others \\
\hline & $46 \%$ wrought aluminum \\
& $41 \%$ wood \\
& $11 \%$ steel \\
& $1 \%$ rubber \\
\hline & $\sim 1 \%$ others (cast aluminum, stainless steel, plastic, copper, brass) \\
\hline
\end{tabular}


Table 24 Material composition of component systems and subsystems in Class 8 day-cab trucks

\begin{tabular}{|c|c|}
\hline Component System/Subsystem & Material Composition \\
\hline \multicolumn{2}{|l|}{ Body (all powertrains) } \\
\hline Body and Glass & $\begin{array}{l}38 \% \text { glass fiber-reinforced plastic } \\
25 \% \text { wrought aluminum } \\
19 \% \text { glass } \\
15 \% \text { steel } \\
4 \% \text { plastic (average) }\end{array}$ \\
\hline Interior & $\begin{array}{l}58 \% \text { steel } \\
33 \% \text { plastic (average) } \\
5 \% \text { cast aluminum } \\
3 \% \text { rubber } \\
1 \% \text { wrought aluminum } \\
\sim 0 \% \text { others (copper/brass, damask, latex, cotton paper, and leather) }\end{array}$ \\
\hline Exterior and Auxiliary & $\begin{array}{l}35 \% \text { plastic } \\
34 \% \text { steel } \\
12 \% \text { rubber } \\
7 \% \text { glass } \\
6 \% \text { cast aluminum } \\
6 \% \text { copper/brass } \\
\sim 0 \% \text { wrought aluminum }\end{array}$ \\
\hline \multicolumn{2}{|l|}{ Chassis (all powertrains) } \\
\hline Steer Axle (including brakes) & $\begin{array}{l}62 \% \text { steel } \\
37 \% \text { cast iron } \\
\sim 1 \% \text { others (cast and wrought aluminum, rubber, plastic, brass, copper, and magnet) }\end{array}$ \\
\hline $\begin{array}{l}\text { Drive Axle (including brakes and } \\
\text { differential assembly) }\end{array}$ & $\begin{array}{l}82 \% \text { steel } \\
17 \% \text { cast iron } \\
\sim 1 \% \text { others (cast aluminum, rubber, plastic, brass, and magnet) }\end{array}$ \\
\hline
\end{tabular}


Table 24 (Cont.)

\begin{tabular}{|c|c|}
\hline Component System/Subsystem & Material Composition \\
\hline \multicolumn{2}{|l|}{ Chassis (all powertrains) } \\
\hline Suspensions (drive and steer axles) & $\begin{array}{l}92 \% \text { steel } \\
6 \% \text { rubber } \\
2 \% \text { cast iron } \\
\sim 0 \% \text { plastic }\end{array}$ \\
\hline $\begin{array}{l}\text { Shafts (driveshaft, inter-axle shaft, } \\
\text { and axle shaft) }\end{array}$ & $\begin{array}{l}96 \% \text { steel } \\
4 \% \text { cast iron } \\
\sim 0 \% \text { others (rubber, plastic, and grease) }\end{array}$ \\
\hline Wheels (steer and drive) & $100 \%$ aluminum \\
\hline Tires (steer and drive) & $\begin{array}{l}66.7 \% \text { rubber } \\
33 \% \text { steel }\end{array}$ \\
\hline Cradle, Fifth-wheel, and Auxiliary & $100 \%$ steel \\
\hline \multicolumn{2}{|l|}{ Powertrain } \\
\hline $\begin{array}{l}\text { Engine Unit (inclusive of powertrain } \\
\text { thermal and electrical system, and } \\
\text { emission control electronics; ICEV } \\
\text { and HEV powertrains) }\end{array}$ & $\begin{array}{l}46 \% \text { steel } \\
37 \% \text { cast iron } \\
8 \% \text { cast aluminum } \\
3 \% \text { wrought aluminum } \\
3 \% \text { plastic } \\
1 \% \text { each, rubber, and copper } \\
\sim 1 \% \text { others (stainless steel, iron, nichrome, and others) }\end{array}$ \\
\hline
\end{tabular}


Table 24 (Cont.)

\begin{tabular}{|c|c|}
\hline Component System/Subsystem & Material Composition \\
\hline \multicolumn{2}{|l|}{ Powertrain } \\
\hline $\begin{array}{c}\text { Fuel-cell Stack } \\
\text { (FCV powertrain) }\end{array}$ & $\begin{array}{l}52 \% \text { stainless steel } \\
10 \% \text { PP } \\
7 \% \text { cast aluminum } \\
6 \% \text { each of steel and wrought aluminum } \\
4 \% \text { glass fiber-reinforced plastic } \\
3 \% \text { PET } \\
2 \% \text { plastic (polyphenylene sulfide and other plastics) } \\
2 \% \text { each of average plastic, copper/brass, and carbon } \\
1 \% \text { each of carbon paper, rubber, and PFSA } \\
0 \% \text { others (PTFE, nickel, iron, nylon, chromium, platinum, HDPE, molybdenum, glass, ceramic, } \\
\text { niobium, titanium, cast iron, bronze, graphite, fiberglass, nichrome, PFSA Nafion, and others) }\end{array}$ \\
\hline $\begin{array}{l}\text { Engine Fuel Storage } \\
+ \text { Exhaust Systems } \\
\text { (ICEV and HEV powertrains) }\end{array}$ & $\begin{array}{l}44 \% \text { wrought aluminum } \\
23 \% \text { ceramic } \\
16 \% \text { plastic (average) } \\
13 \% \text { stainless steel } \\
4 \% \text { steel } \\
\sim 0 \% \text { others (rubber and platinum) }\end{array}$ \\
\hline $\begin{array}{l}\text { Transmission } \\
\text { (all powertrains) }\end{array}$ & $\begin{array}{l}86 \% \text { steel } \\
7 \% \text { cast iron } \\
5 \% \text { plastic } \\
\sim 2 \% \text { others (cast and wrought aluminum, rubber, plastic, copper, brass, magnet, and grease) }\end{array}$ \\
\hline \multicolumn{2}{|c|}{ Electric-drive Components (HEV, EV, and FCV powertrains) } \\
\hline Traction Motor and Generator & $\begin{array}{l}36 \% \text { steel } \\
36 \% \text { cast aluminum } \\
28 \% \text { copper and brass }\end{array}$ \\
\hline
\end{tabular}


Table 24 (Cont.)

\begin{tabular}{|c|c|}
\hline Component System/Subsystem & Material Composition \\
\hline \multicolumn{2}{|c|}{ Electric-drive Components (HEV, EV, and FCV powertrains) } \\
\hline Electronic Controller & $\begin{array}{l}5 \% \text { steel } \\
47 \% \text { cast aluminum } \\
8 \% \text { copper and brass } \\
4 \% \text { rubber } \\
24 \% \text { average plastic } \\
12 \% \text { others }\end{array}$ \\
\hline $\begin{array}{l}\text { Fuel-cell Onboard Storage } \\
\text { (FCV powertrain) }\end{array}$ & $\begin{array}{l}64 \% \text { carbon fiber-reinforced composite } \\
29 \% \text { stainless steel } \\
3 \% \text { wrought aluminum } \\
2 \% \text { each of HDPE and PP } \\
1 \% \text { steel } \\
\sim 0 \% \text { others }\end{array}$ \\
\hline \multicolumn{2}{|l|}{ Trailer (all powertrains) } \\
\hline Trailer Body & $\begin{array}{l}51 \% \text { wrought aluminum } \\
38 \% \text { wood } \\
11 \% \text { steel } \\
\sim 0 \% \text { others (cast aluminum and rubber) } \\
\end{array}$ \\
\hline Trailer Chassis & $\begin{array}{l}57 \% \text { steel } \\
19 \% \text { rubber } \\
13 \% \text { cast iron } \\
9 \% \text { cast aluminum } \\
2 \% \text { ceramic } \\
\sim 0 \% \text { others (stainless steel, wrought aluminum, plastic, grease, and magnets) }\end{array}$ \\
\hline Trailer Auxiliary & $\begin{array}{l}69 \% \text { steel } \\
17 \% \text { glass fiber-reinforced plastic } \\
6 \% \text { wrought aluminum } \\
5 \% \text { rubber } \\
\sim 3 \% \text { others (stainless steel, plastic, copper, brass, and others) }\end{array}$ \\
\hline
\end{tabular}


Table 25 Material composition of component systems/subsystems in Class 8 sleeper-cab trucks

\begin{tabular}{|c|c|}
\hline Component System/Subsystem & Material Composition \\
\hline \multicolumn{2}{|l|}{ Body (all powertrains) } \\
\hline Body and Glass & $\begin{array}{l}36 \% \text { glass fiber-reinforced plastic } \\
23 \% \text { wrought aluminum } \\
19 \% \text { steel } \\
18 \% \text { glass } \\
3 \% \text { plastic (average) }\end{array}$ \\
\hline Interior & $\begin{array}{l}49 \% \text { steel } \\
25 \% \text { plastic (average) } \\
7 \% \text { damask } \\
5 \% \text { each of latex and cast aluminum } \\
4 \% \text { leather } \\
3 \% \text { rubber } \\
1 \% \text { wrought aluminum } \\
\sim 0 \% \text { others (copper/brass and cotton paper) }\end{array}$ \\
\hline Exterior and Auxiliary & $\begin{array}{l}43 \% \text { plastic } \\
24 \% \text { steel } \\
10 \% \text { each of cast aluminum and glass } \\
8 \% \text { rubber } \\
4 \% \text { copper/brass } \\
\sim 0 \% \text { wrought aluminum } \\
\end{array}$ \\
\hline \multicolumn{2}{|l|}{ Chassis (all powertrains) } \\
\hline Wheels (steer and drive) & $100 \%$ aluminum \\
\hline Tires (steer and drive) & $\begin{array}{l}66.7 \% \text { rubber } \\
33 \% \text { steel }\end{array}$ \\
\hline Steer Axle (including brakes) & $\begin{array}{l}62 \% \text { steel } \\
37 \% \text { cast iron } \\
\sim 1 \% \text { others (cast and wrought aluminum, rubber, plastic, brass, copper, and magnet) }\end{array}$ \\
\hline $\begin{array}{l}\text { Drive Axle (including brakes and } \\
\text { differential assembly) }\end{array}$ & $\begin{array}{l}82 \% \text { steel } \\
17 \% \text { cast iron } \\
\sim 1 \% \text { others (cast aluminum, rubber, plastic, brass, and magnet) }\end{array}$ \\
\hline
\end{tabular}


Table 25 (Cont.)

\begin{tabular}{|c|c|}
\hline Component System/Subsystem & Material Composition \\
\hline \multicolumn{2}{|l|}{ Chassis (all powertrains) } \\
\hline Suspensions (drive and steer axles) & $\begin{array}{l}92 \% \text { steel } \\
2 \% \text { cast iron } \\
6 \% \text { rubber } \\
\sim 0 \% \text { plastic }\end{array}$ \\
\hline $\begin{array}{l}\text { Shafts (driveshaft, inter-axle shaft, } \\
\text { and axle shaft) }\end{array}$ & $\begin{array}{l}96 \% \text { steel } \\
4 \% \text { cast iron } \\
\sim 0 \% \text { others (rubber, plastic, and grease) }\end{array}$ \\
\hline Cradle, Fifth-wheel, and Auxiliary & $\begin{array}{l}98 \% \text { steel } \\
2 \% \text { rubber }\end{array}$ \\
\hline \multicolumn{2}{|l|}{ Powertrain } \\
\hline $\begin{array}{l}\text { Engine Unit (inclusive of powertrain } \\
\text { thermal and electrical system, and } \\
\text { emission control electronics; ICEV } \\
\text { and HEV powertrains) }\end{array}$ & $\begin{array}{l}46 \% \text { steel } \\
37 \% \text { cast iron } \\
8 \% \text { cast aluminum } \\
3 \% \text { wrought aluminum } \\
3 \% \text { plastic } \\
3 \% \text { (rubber, copper, stainless steel, iron, nichrome, and others) }\end{array}$ \\
\hline $\begin{array}{l}\text { Fuel-cell Stack } \\
\text { (FCV powertrain) }\end{array}$ & $\begin{array}{l}52 \% \text { stainless steel } \\
10 \% \text { PP } \\
7 \% \text { cast aluminum } \\
6 \% \text { each of steel and wrought aluminum } \\
4 \% \text { glass fiber-reinforced plastic } \\
3 \% \text { PET } \\
2 \% \text { plastic (polyphenylene sulfide and other plastics) } \\
2 \% \text { each of average plastic, copper/brass, and carbon } \\
1 \% \text { each of carbon paper, rubber, and PFSA } \\
0 \% \text { others (PTFE, nickel, iron, nylon, chromium, platinum, HDPE, molybdenum, glass, ceramic, } \\
\text { niobium, titanium, cast iron, bronze, graphite, fiberglass, nichrome, PFSA Nafion, and others) }\end{array}$ \\
\hline
\end{tabular}


Table 25 (Cont.)

\begin{tabular}{|c|c|}
\hline Component System/Subsystem & Material Composition \\
\hline \multicolumn{2}{|l|}{ Powertrain } \\
\hline $\begin{array}{c}\text { Engine Fuel Storage } \\
\text { + Exhaust Systems } \\
\text { (ICEV and HEV powertrains) }\end{array}$ & $\begin{array}{l}35 \% \text { wrought aluminum } \\
23 \% \text { ceramic } \\
19 \% \text { plastic (average) } \\
13 \% \text { stainless steel } \\
10 \% \text { steel } \\
\sim 0 \% \text { others (rubber and platinum) }\end{array}$ \\
\hline Transmission (all powertrains) & $\begin{array}{l}86 \% \text { steel } \\
7 \% \text { cast iron } \\
5 \% \text { plastic } \\
1 \% \text { rubber } \\
\sim 1 \% \text { others (cast aluminum, wrought aluminum, rubber, plastic, copper, brass, magnet, and grease) }\end{array}$ \\
\hline \multicolumn{2}{|c|}{ Electric-drive Components (HEV, EV, and FCV powertrains) } \\
\hline Traction Motor and Generator & $\begin{array}{l}36 \% \text { steel } \\
36 \% \text { cast aluminum } \\
28 \% \text { copper and brass }\end{array}$ \\
\hline Electronic Controller & $\begin{array}{l}5 \% \text { steel } \\
47 \% \text { cast aluminum } \\
8 \% \text { copper and brass } \\
4 \% \text { rubber } \\
24 \% \text { average plastic } \\
12 \% \text { others }\end{array}$ \\
\hline $\begin{array}{l}\text { Fuel-cell Onboard Storage } \\
\text { (FCV powertrain) }\end{array}$ & $\begin{array}{l}55 \% \text { carbon fiber-reinforced composite } \\
39 \% \text { stainless steel } \\
2 \% \text { each of wrought aluminum and HDPE } \\
1 \% \text { each of steel and PP } \\
\sim 0 \% \text { others }\end{array}$ \\
\hline
\end{tabular}


Table 25 (Cont.)

\begin{tabular}{|c|c|}
\hline Component System/Subsystem & Material Composition \\
\hline \multicolumn{2}{|l|}{ Trailer (all powertrains) } \\
\hline Trailer Body & $\begin{array}{l}51 \% \text { wrought aluminum } \\
38 \% \text { wood } \\
11 \% \text { steel } \\
\sim 0 \% \text { others (cast aluminum and rubber) }\end{array}$ \\
\hline Trailer Chassis & $\begin{array}{l}58 \% \text { steel } \\
18 \% \text { rubber } \\
14 \% \text { cast iron } \\
9 \% \text { cast aluminum } \\
\sim 1 \% \text { others (ceramic, stainless steel, wrought aluminum, plastic, grease, and magnets) }\end{array}$ \\
\hline Trailer Auxiliary & $\begin{array}{l}69 \% \text { steel } \\
17 \% \text { glass fiber-reinforced plastic } \\
6 \% \text { wrought aluminum } \\
5 \% \text { rubber } \\
\sim 3 \% \text { others (stainless steel, plastic, copper, brass, and others) }\end{array}$ \\
\hline
\end{tabular}


Table 26 Material composition of Class 6 PnD trucks (aggregated over all component systems; wt. \%)

\begin{tabular}{|c|c|c|c|c|}
\hline Materials & ICEV & HEV & $\mathbf{E V}$ & FCV \\
\hline Steel & 49.4 & 49.4 & 50.6 & 47.8 \\
\hline Stainless Steel & 0.9 & 0.9 & 0.6 & 2.3 \\
\hline Cast Iron & 7.2 & 6.9 & 4.0 & 3.7 \\
\hline Cast Aluminum & 3.1 & 3.4 & 3.7 & 3.7 \\
\hline Wrought Aluminum & 15.5 & 15.4 & 15.8 & 15.2 \\
\hline Copper and Brass & 0.1 & 0.3 & 0.7 & 0.8 \\
\hline Magnet & 0.0 & 0.0 & 0.0 & 0.0 \\
\hline Bronze & 0.0 & 0.0 & 0.0 & 0.0 \\
\hline Iron & 0.0 & 0.0 & 0.0 & 0.0 \\
\hline Nichrome & 0.0 & 0.0 & 0.0 & 0.0 \\
\hline Nickel & 0.0 & 0.0 & 0.0 & 0.0 \\
\hline Chromium & 0.0 & 0.0 & 0.0 & 0.0 \\
\hline Molybdenum & 0.0 & 0.0 & 0.0 & 0.0 \\
\hline Niobium & 0.0 & 0.0 & 0.0 & 0.0 \\
\hline Titanium & 0.0 & 0.0 & 0.0 & 0.0 \\
\hline Platinum & 0.0 & 0.0 & 0.0 & 0.0 \\
\hline Rubber & 4.1 & 4.1 & 4.5 & 4.3 \\
\hline Plastic (average) & 2.9 & 2.9 & 2.6 & 2.6 \\
\hline Nylon & 0.0 & 0.0 & 0.0 & 0.0 \\
\hline $\mathrm{PP}$ & 0.0 & 0.0 & 0.0 & 0.5 \\
\hline HDPE & 0.0 & 0.0 & 0.0 & 0.1 \\
\hline PET & 0.0 & 0.0 & 0.0 & 0.1 \\
\hline PTFE & 0.0 & 0.0 & 0.0 & 0.0 \\
\hline PFSA & 0.0 & 0.0 & 0.0 & 0.0 \\
\hline Plastic (PPS and others) & 0.0 & 0.0 & 0.0 & 0.1 \\
\hline PFSA Nafion & 0.0 & 0.0 & 0.0 & 0.0 \\
\hline Carbon Fiber-reinforced Plastic & 0.0 & 0.0 & 0.0 & 2.2 \\
\hline Glass Fiber-reinforced Plastic & 2.6 & 2.6 & 2.8 & 2.7 \\
\hline Fiberglass & 0.0 & 0.0 & 0.0 & 0.0 \\
\hline Glass & 1.5 & 1.5 & 1.6 & 1.5 \\
\hline Graphite & 0.0 & 0.0 & 0.0 & 0.0 \\
\hline Ceramic & 0.6 & 0.6 & 0.0 & 0.0 \\
\hline Carbon & 0.0 & 0.0 & 0.0 & 0.1 \\
\hline Cotton Paper & 0.0 & 0.0 & 0.0 & 0.0 \\
\hline Grease & 0.0 & 0.0 & 0.0 & 0.0 \\
\hline Damask & 0.0 & 0.0 & 0.0 & 0.0 \\
\hline Latex & 0.0 & 0.0 & 0.0 & 0.0 \\
\hline Leather & 0.2 & 0.2 & 0.2 & 0.2 \\
\hline Silica & 0.0 & 0.0 & 0.0 & 0.0 \\
\hline Carbon Paper & 0.0 & 0.0 & 0.0 & 0.0 \\
\hline Wood & 11.7 & 11.7 & 12.8 & 12.0 \\
\hline Others & 0.0 & 0.0 & 0.0 & 0.0 \\
\hline
\end{tabular}


Table 27 Material composition of Class 8 day-cab trucks (aggregated over all component systems; wt.\%)

\begin{tabular}{|c|c|c|c|c|}
\hline Materials & ICEV & HEV & $\mathbf{E V}$ & FCV \\
\hline Steel & 50.8 & 50.7 & 50.7 & 44.2 \\
\hline Stainless Steel & 0.6 & 0.5 & 0.4 & 5.6 \\
\hline Cast Iron & 8.8 & 8.7 & 5.6 & 4.9 \\
\hline Cast Aluminum & 4.6 & 4.9 & 5.4 & 5.1 \\
\hline Wrought Aluminum & 13.2 & 13.1 & 13.7 & 12.4 \\
\hline Copper and Brass & 0.2 & 0.4 & 0.9 & 0.9 \\
\hline Magnet & 0.0 & 0.0 & 0.0 & 0.0 \\
\hline Bronze & 0.0 & 0.0 & 0.0 & 0.0 \\
\hline Iron & 0.0 & 0.0 & 0.0 & 0.0 \\
\hline Nichrome & 0.0 & 0.0 & 0.0 & 0.0 \\
\hline Nickel & 0.0 & 0.0 & 0.0 & 0.0 \\
\hline Chromium & 0.0 & 0.0 & 0.0 & 0.0 \\
\hline Molybdenum & 0.0 & 0.0 & 0.0 & 0.0 \\
\hline Niobium & 0.0 & 0.0 & 0.0 & 0.0 \\
\hline Titanium & 0.0 & 0.0 & 0.0 & 0.0 \\
\hline Platinum & 0.0 & 0.0 & 0.0 & 0.0 \\
\hline Rubber & 7.3 & 7.2 & 8.0 & 7.0 \\
\hline Plastic (average) & 2.1 & 2.1 & 1.7 & 1.6 \\
\hline Nylon & 0.0 & 0.0 & 0.0 & 0.0 \\
\hline PP & 0.0 & 0.0 & 0.0 & 0.7 \\
\hline HDPE & 0.0 & 0.0 & 0.0 & 0.2 \\
\hline PET & 0.0 & 0.0 & 0.0 & 0.2 \\
\hline PTFE & 0.0 & 0.0 & 0.0 & 0.0 \\
\hline PFSA & 0.0 & 0.0 & 0.0 & 0.0 \\
\hline Plastic (PPS and others) & 0.0 & 0.0 & 0.0 & 0.1 \\
\hline PFSA Nafion & 0.0 & 0.0 & 0.0 & 0.0 \\
\hline Carbon Fiber-reinforced Plastic & 0.0 & 0.0 & 0.0 & 5.1 \\
\hline Glass Fiber-reinforced Plastic & 2.6 & 2.6 & 2.9 & 2.7 \\
\hline Fiberglass & 0.0 & 0.0 & 0.0 & 0.0 \\
\hline Glass & 1.2 & 1.1 & 1.3 & 1.1 \\
\hline Graphite & 0.0 & 0.0 & 0.0 & 0.0 \\
\hline Ceramic & 0.6 & 0.6 & 0.3 & 0.3 \\
\hline Carbon & 0.0 & 0.0 & 0.0 & 0.1 \\
\hline Cotton Paper & 0.0 & 0.0 & 0.0 & 0.0 \\
\hline Grease & 0.0 & 0.0 & 0.0 & 0.0 \\
\hline Damask & 0.0 & 0.0 & 0.0 & 0.0 \\
\hline Latex & 0.0 & 0.0 & 0.0 & 0.0 \\
\hline Leather & 0.0 & 0.0 & 0.0 & 0.0 \\
\hline Silica & 0.0 & 0.0 & 0.0 & 0.0 \\
\hline Carbon Paper & 0.0 & 0.0 & 0.0 & 0.1 \\
\hline Wood & 8.0 & 8.0 & 9.0 & 7.7 \\
\hline Others & 0.0 & 0.0 & 0.0 & 0.0 \\
\hline
\end{tabular}


Table 28 Material composition of Class 8 sleeper-cab trucks (aggregated over all component systems; wt.\%)

\begin{tabular}{|c|c|c|c|c|}
\hline Materials & ICEV & HEV & EV & FCV \\
\hline Steel & 51.5 & 51.4 & 51.5 & 42.0 \\
\hline Stainless Steel & 0.5 & 0.5 & 0.3 & 8.4 \\
\hline Cast Iron & 8.5 & 8.4 & 5.5 & 4.5 \\
\hline Cast Aluminum & 4.3 & 4.6 & 5.0 & 4.4 \\
\hline Wrought Aluminum & 12.7 & 12.6 & 13.2 & 11.3 \\
\hline Copper and Brass & 0.2 & 0.3 & 0.8 & 0.7 \\
\hline Magnet & 0.0 & 0.0 & 0.0 & 0.0 \\
\hline Bronze & 0.0 & 0.0 & 0.0 & 0.0 \\
\hline Iron & 0.0 & 0.0 & 0.0 & 0.0 \\
\hline Nichrome & 0.0 & 0.0 & 0.0 & 0.0 \\
\hline Nickel & 0.0 & 0.0 & 0.0 & 0.0 \\
\hline Chromium & 0.0 & 0.0 & 0.0 & 0.0 \\
\hline Molybdenum & 0.0 & 0.0 & 0.0 & 0.0 \\
\hline Niobium & 0.0 & 0.0 & 0.0 & 0.0 \\
\hline Titanium & 0.0 & 0.0 & 0.0 & 0.0 \\
\hline Platinum & 0.0 & 0.0 & 0.0 & 0.0 \\
\hline Rubber & 6.8 & 6.8 & 7.5 & 6.1 \\
\hline Plastic (average) & 2.9 & 2.9 & 2.5 & 2.2 \\
\hline Nylon & 0.0 & 0.0 & 0.0 & 0.0 \\
\hline PP & 0.0 & 0.0 & 0.0 & 0.7 \\
\hline HDPE & 0.0 & 0.0 & 0.0 & 0.2 \\
\hline PET & 0.0 & 0.0 & 0.0 & 0.1 \\
\hline PTFE & 0.0 & 0.0 & 0.0 & 0.0 \\
\hline PFSA & 0.0 & 0.0 & 0.0 & 0.0 \\
\hline Plastic (PPS and others) & 0.0 & 0.0 & 0.0 & 0.1 \\
\hline PFSA Nafion & 0.0 & 0.0 & 0.0 & 0.0 \\
\hline Carbon Fiber-reinforced Plastic & 0.0 & 0.0 & 0.0 & 7.8 \\
\hline Glass Fiber-reinforced Plastic & 2.2 & 2.1 & 2.4 & 2.1 \\
\hline Fiberglass & 0.0 & 0.0 & 0.0 & 0.0 \\
\hline Glass & 1.0 & 1.0 & 1.2 & 0.9 \\
\hline Graphite & 0.0 & 0.0 & 0.0 & 0.0 \\
\hline Ceramic & 0.6 & 0.6 & 0.3 & 0.2 \\
\hline Carbon & 0.0 & 0.0 & 0.0 & 0.1 \\
\hline Cotton Paper & 0.0 & 0.0 & 0.0 & 0.0 \\
\hline Grease & 0.0 & 0.0 & 0.0 & 0.0 \\
\hline Damask & 0.4 & 0.4 & 0.4 & 0.3 \\
\hline Latex & 0.3 & 0.3 & 0.3 & 0.3 \\
\hline Leather & 0.2 & 0.2 & 0.2 & 0.2 \\
\hline Silica & 0.0 & 0.0 & 0.0 & 0.0 \\
\hline Carbon Paper & 0.0 & 0.0 & 0.0 & 0.1 \\
\hline Wood & 8.0 & 7.9 & 8.8 & 7.1 \\
\hline Others & 0.0 & 0.0 & 0.0 & 0.0 \\
\hline
\end{tabular}




\subsection{Fuel-cell Components and Batteries: Sizing, Weight, and Material Composition}

Fuel-cell stack net power values, based on Autonomie results (Argonne National Laboratory, 2021), are provided in Table 29. Since these power values are different from those obtained from SA (James et al., 2021), the weight-to-power ratio for SA's fuel-cell stack is used to obtain the weight of the fuel-cell stack to coincide with the power requirement as defined by Autonomie. The weight-to-power ratio for each MHDV is used to calculate the total weight and weight break-up (by individual parts) for fuel-cell stack systems for MHDVs, with the total weight values given in Table 30.

Table 29 Net fuel-cell stack power values (in $\mathrm{kW}$ ) for different vehicles for both Autonomie and SA

\begin{tabular}{|c|c|c|}
\hline \multirow{2}{*}{ Type of MHDV } & \multicolumn{2}{|c|}{ Net Fuel-cell Stack Power Values (kW) } \\
\cline { 2 - 3 } & Autonomie & SA \\
\hline Class 6 PnD & 195 & 160 \\
\hline Class 8 Day-cab & 428 & 275 \\
\hline Class 8 Sleeper-cab & 426 & 275 \\
\hline
\end{tabular}

Table 30 Total weight of fuel-cell stack system (lbs.) for MHDVs for both Autonomie and SA

\begin{tabular}{|c|c|c|}
\hline \multirow{2}{*}{ Type of MHDV } & \multicolumn{2}{|c|}{ Weight of Fuel-cell Stack System (lbs.) } \\
\cline { 2 - 3 } & Autonomie & SA \\
\hline Class 6 PnD & 558 & 476 \\
\hline Class 8 Day-cab & 1,532 & 1,021 \\
\hline Class 8 Sleeper-cab & 1,525 & 1,021 \\
\hline
\end{tabular}

On the other hand, for fuel-cell onboard storage (or hydrogen tank storage systems), calculations made by SA are used to obtain their final weight and break-up (by constituent components) after modifying: (a) the total weight of hydrogen stored (in line with the amount given by Autonomie); and (b) the number of tanks for all fuel-cell MHDVs (assuming the maximum storage of $10 \mathrm{~kg}$ of hydrogen per tank). Two scenarios are considered regarding the pressure of hydrogen stored in these tanks: 700-bar (the default scenario, for which data/weight values are used in Tables 17-28) and 350-bar.

Table 31 shows the overall weight and material composition of fuel-cell onboard storage (hydrogen tanks + other balance of plant) for both pressure scenarios for all MHDVs, while Table 32 shows the number of hydrogen tanks and total amount of hydrogen stored in these vehicles for both these pressure scenarios. 
Table 31 Material composition and weight of 700-bar and 350-bar fuel-cell onboard storage systems for all MHDVs

\begin{tabular}{|c|c|c|c|c|c|c|}
\hline \multirow{2}{*}{ Materials } & \multicolumn{2}{|c|}{$\begin{array}{c}\text { Class 6 PnD: } \\
\text { Weight Share } \\
\text { (wt.\%) }\end{array}$} & $\begin{array}{c}\text { Class 8 Day-cab: } \\
\text { Weight Share } \\
\text { (wt.\%) }\end{array}$ & $\begin{array}{c}\text { Class 8 Sleeper- } \\
\text { cab: Weight Share } \\
\text { (wt.\%) }\end{array}$ \\
\cline { 2 - 7 } & $\begin{array}{c}\text { 700-bar } \\
\text { 350-bar }\end{array}$ & $\begin{array}{c}\text { 700-bar } \\
\text { 350-bar }\end{array}$ & $\begin{array}{c}\text { 700-bar } \\
\text { 350-bar }\end{array}$ \\
\hline Carbon Fiber-reinforced Plastic & 73.4 & 53.0 & 63.5 & 35.8 & 54.5 & 28.3 \\
\hline Steel & 2.8 & 1.2 & 1.2 & 0.6 & 0.8 & 0.4 \\
\hline Stainless Steel & 13.2 & 29.6 & 28.6 & 53.3 & 39.3 & 63.2 \\
\hline Glass Fiber-reinforced Plastic & 0.0 & 0.0 & 0.0 & 0.0 & 0.0 & 0.0 \\
\hline Wrought Aluminum & 6.1 & 7.3 & 3.2 & 4.4 & 2.4 & 3.4 \\
\hline Copper & 0.0 & 0.0 & 0.0 & 0.0 & 0.0 & 0.0 \\
\hline PP & 1.8 & 4.0 & 1.5 & 2.7 & 1.3 & 2.1 \\
\hline HDPE & 2.7 & 4.9 & 2.0 & 3.2 & 1.7 & 2.6 \\
\hline Others & 0.0 & 0.0 & 0.0 & 0.0 & 0.0 & 0.0 \\
\hline
\end{tabular}

Table 32 Number of hydrogen tanks and overall hydrogen amount stored in MHDVs as per SA

\begin{tabular}{|c|c|c|c|}
\hline \multirow{2}{*}{ Type of MHDV } & \multirow{2}{*}{ Amount of Hydrogen Stored (kg) } & \multicolumn{2}{|c|}{ Number of Tanks Used } \\
\cline { 3 - 4 } & & $\mathbf{7 0 0 - b a r}$ & 350-bar \\
\hline Class 6 PnD & 11 & 2 & 3 \\
\hline Class 8 Day-cab & 43 & 5 & 8 \\
\hline Class 8 Sleeper-cab & 77 & 8 & 12 \\
\hline
\end{tabular}

Since the fuel-cell stack power values are typically in line with battery power requirements for hybrid FCVs, battery power values for Li-ion batteries are also chosen from Autonomie (Argonne National Laboratory, 2021), which are provided in Table 33. Similar to fuel-cell stack sizing, HEV Li-ion batteries are sized by power, with their power values also taken from Autonomie (Table 33). Conversely, unlike for HEVs and FCVs, EV Li-ion batteries are sized by energy. These energy values, taken from Autonomie, are shown in Table 34. These power values (for HEVs and FCVs) and energy values (for EVs) are inputted in the BatPaC 4.0 model (Argonne National Laboratory, 2018) to determine the total weight of Li-ion batteries for HEV, EV, and FCV MHDVs. BatPaC was used because it computes bottom-up weight and material composition estimates of Li-ion batteries based on specific battery parameters (battery energy/power requirement as provided in Autonomie, and other parameters, such as number of cells/module, number of modules/battery, and current). For MHDVs, we modeled four cathode options for HEV and FCV MHDVs and three options for EV MHDVs, all based on the NMC (nickel-manganese-cobalt) chemistry (NMC811, NMC622, NMC532, and NMC111, with the last used only in HEV and FCV MHDVs). Specific power and energy values of these options, as obtained via BatPaC 4.0 model, are provided in Table 35. Along with these values, material composition and overall weight of Li-ion batteries (all NMC options) across all these powertrains are provided in Tables 36-44. 
Table 33 Battery power values (in $\mathrm{kW}$ ) for HEV and FCV MHDVs, taken from Autonomie

\begin{tabular}{|c|c|c|}
\hline \multirow{2}{*}{ Type of MHDV } & \multicolumn{2}{|c|}{ Power Values (kW) for Li-ion Batteries } \\
\cline { 2 - 3 } & HEV & FCV \\
\hline Class 6 PnD & 157 & 190 \\
\hline Class 8 Day-cab & 219 & 112 \\
\hline Class 8 Sleeper-cab & 219 & 112 \\
\hline
\end{tabular}

Table 34 Battery energy values (in kWh) for EV MHDVs, taken from Autonomie

\begin{tabular}{|c|c|}
\hline Type of MHDV & $\begin{array}{c}\text { Energy Requirement for EV MHDVs (kWh) from Li- } \\
\text { ion Batteries }\end{array}$ \\
\hline Class 6 PnD & 261 \\
\hline Class 8 Day-cab & 909 \\
\hline Class 8 Sleeper-cab & 1,622 \\
\hline
\end{tabular}

Table 35 Specific power and energy values of $\mathrm{Li}$-ion batteries for different MHDVs

\begin{tabular}{|c|c|c|c|c|}
\hline \multirow{2}{*}{ Type of MHDV } & $\begin{array}{c}\text { Li-ion Battery } \\
\text { Chemistry }\end{array}$ & Specific Power (W/kg) & Specific Energy (Wh/kg) \\
\cline { 2 - 5 } & HEV & FCV & EV \\
\hline \multirow{3}{*}{ Class 6 PnD } & NMC811 & 2,760 & 2,969 & 162 \\
\cline { 2 - 5 } & NMC622 & 2,650 & 2,844 & 154 \\
\cline { 2 - 5 } & NMC532 & 2,546 & 2,740 & 146 \\
\cline { 2 - 5 } & NMC111 & 2,519 & 2,697 & N/A \\
\hline \multirow{3}{*}{ Class 8 Day-cab } & NMC811 & 3,112 & 1,215 & 207 \\
\cline { 2 - 5 } & NMC622 & 2,808 & 1,164 & 196 \\
\cline { 2 - 5 } & NMC532 & 2,694 & 1,112 & 183 \\
\cline { 2 - 5 } & NMC111 & 2,652 & 1,094 & N/A \\
\hline Class 8 Sleeper-cab & NMC811 & 3,112 & 1,271 & 223 \\
\cline { 2 - 5 } & NMC622 & 2,808 & 1,214 & 210 \\
\cline { 2 - 5 } & NMC532 & 2,694 & 1,166 & 196 \\
\cline { 2 - 5 } & NMC111 & 2,652 & 1,147 & N/A \\
\hline
\end{tabular}


Table 36 Material composition of Li-ion batteries in Class 6 PnD trucks (HEV) (\%)

\begin{tabular}{|c|c|c|c|c|}
\hline \multirow{2}{*}{ Materials } & \multicolumn{4}{|c|}{ Material Composition (wt.\%) } \\
\cline { 2 - 4 } & NMC811 & NMC622 & NMC532 & NMC111 \\
\hline Cathode (active material) & 11.1 & 12.5 & 13.8 & 14.1 \\
\hline Graphite/Carbon Anode & 8.2 & 7.9 & 7.8 & 7.7 \\
\hline Silicon & 0.0 & 0.0 & 0.0 & 0.0 \\
\hline Binder (polyvinylidene fluoride, or PVDF) & 0.4 & 0.4 & 0.4 & 0.4 \\
\hline Copper & 24.7 & 24.5 & 24.0 & 24.2 \\
\hline Wrought Aluminum & 25.7 & 25.4 & 25.1 & 25.0 \\
\hline Cast Aluminum & 0.0 & 0.0 & 0.0 & 0.0 \\
\hline LiPF & 0.9 & 0.9 & 1.0 & 1.0 \\
\hline Ethylene Carbonate & 2.6 & 2.6 & 2.7 & 2.7 \\
\hline Dimethyl Carbonate & 2.6 & 2.6 & 2.7 & 2.7 \\
\hline PP & 1.1 & 1.1 & 1.1 & 1.1 \\
\hline Polyethylene (PE) & 0.6 & 0.6 & 0.6 & 0.6 \\
\hline PET & 0.3 & 0.3 & 0.3 & 0.3 \\
\hline Steel & 0.7 & 0.7 & 0.7 & 0.7 \\
\hline Thermal Insulation & 1.6 & 1.6 & 1.5 & 1.5 \\
\hline Glycol & 12.5 & 12.1 & 11.9 & 11.6 \\
\hline Electronic Parts (battery management & \multirow{2}{*}{6.8} & 6.6 & 6.3 & 6.2 \\
\hline system, or BMS) & & & & \\
\hline
\end{tabular}

Table 37 Material composition of Li-ion batteries in Class 6 PnD trucks (EV) (\%)

\begin{tabular}{|c|c|c|c|}
\hline \multirow{2}{*}{ Materials } & \multicolumn{3}{|c|}{ Material Composition (wt.\%) } \\
\cline { 2 - 4 } & NMC811 & NMC622 & NMC532 \\
\hline Cathode (active material) & 20.4 & 22.9 & 24.9 \\
\hline Graphite/Carbon Anode & 14.7 & 14.0 & 13.6 \\
\hline Silicon & 0.0 & 0.0 & 0.0 \\
\hline Binder (PVDF) & 0.7 & 0.8 & 0.8 \\
\hline Copper & 16.4 & 15.7 & 15.2 \\
\hline Wrought Aluminum & 31.4 & 30.5 & 29.7 \\
\hline Cast Aluminum & 0.0 & 0.0 & 0.0 \\
\hline LiPF $_{\text {Ethylene Carbonate }}$ & 1.1 & 1.1 & 1.1 \\
\hline Dimethyl Carbonate & 3.0 & 3.0 & 3.0 \\
\hline PP & 3.0 & 3.0 & 3.0 \\
\hline PE & 1.2 & 1.2 & 1.1 \\
\hline PET & 0.5 & 0.5 & 0.5 \\
\hline Steel & 0.2 & 0.2 & 0.2 \\
\hline Thermal Insulation & 0.1 & 0.1 & 0.1 \\
\hline Glycol & 0.8 & 0.7 & 0.7 \\
\hline Electronic Parts (BMS) & 6.0 & 5.8 & 5.7 \\
\hline
\end{tabular}


Table 38 Material composition of Li-ion batteries in Class 6 PnD trucks (FCV) (\%)

\begin{tabular}{|c|c|c|c|c|}
\hline \multirow{2}{*}{ Materials } & \multicolumn{4}{|c|}{ Material Composition (wt.\%) } \\
\cline { 2 - 4 } & NMC811 & NMC622 & NMC532 & NMC111 \\
\hline Cathode (active material) & 11.8 & 13.3 & 14.7 & 15.0 \\
\hline Graphite/Carbon Anode & 8.7 & 8.4 & 8.3 & 8.1 \\
\hline Silicon & 0.0 & 0.0 & 0.0 & 0.0 \\
\hline Binder (PVDF) & 0.4 & 0.4 & 0.5 & 0.5 \\
\hline Copper & 26.1 & 25.8 & 25.4 & 25.5 \\
\hline Wrought Aluminum & 25.0 & 24.7 & 24.3 & 24.3 \\
\hline Cast Aluminum & 0.0 & 0.0 & 0.0 & 0.0 \\
\hline LiPF & 1.0 & 1.0 & 1.0 & 1.0 \\
\hline Ethylene Carbonate & 2.7 & 2.8 & 2.9 & 2.9 \\
\hline Dimethyl Carbonate & 2.7 & 2.8 & 2.9 & 2.9 \\
\hline PP & 1.2 & 1.2 & 1.2 & 1.2 \\
\hline PE & 0.6 & 0.6 & 0.6 & 0.6 \\
\hline PET & 0.3 & 0.3 & 0.3 & 0.3 \\
\hline Steel & 0.7 & 0.7 & 0.7 & 0.7 \\
\hline Thermal Insulation & 1.7 & 1.6 & 1.6 & 1.6 \\
\hline Glycol & 10.9 & 10.5 & 10.2 & 10.0 \\
\hline Electronic Parts (BMS) & 6.1 & 5.8 & 5.6 & 5.5 \\
\hline
\end{tabular}

Table 39 Material composition of Li-ion batteries in Class 8 day-cab trucks (HEV) (\%)

\begin{tabular}{|c|c|c|c|c|}
\hline \multirow{2}{*}{ Materials } & \multicolumn{4}{|c|}{ Material Composition (wt.\%) } \\
\cline { 2 - 4 } & NMC811 & NMC622 & NMC532 & NMC111 \\
\hline Cathode (active material) & 12.5 & 13.3 & 14.6 & 14.9 \\
\hline Graphite/Carbon Anode & 9.2 & 8.3 & 8.2 & 8.0 \\
\hline Silicon & 0.0 & 0.0 & 0.0 & 0.0 \\
\hline Binder (PVDF) & 0.4 & 0.4 & 0.5 & 0.5 \\
\hline Copper & 27.0 & 25.1 & 24.6 & 24.7 \\
\hline Wrought Aluminum & 24.4 & 28.2 & 27.8 & 27.7 \\
\hline Cast Aluminum & 0.0 & 0.0 & 0.0 & 0.0 \\
\hline LiPF & 1.0 & 1.0 & 1.0 & 1.0 \\
\hline Ethylene Carbonate & 2.9 & 2.8 & 2.8 & 2.8 \\
\hline Dimethyl Carbonate & 2.9 & 2.8 & 2.8 & 2.8 \\
\hline PP & 1.2 & 1.2 & 1.1 & 1.1 \\
\hline PE & 0.6 & 0.5 & 0.5 & 0.5 \\
\hline PET & 0.3 & 0.3 & 0.3 & 0.3 \\
\hline Steel & 0.7 & 0.6 & 0.6 & 0.6 \\
\hline Thermal Insulation & 1.7 & 1.7 & 1.7 & 1.7 \\
\hline Glycol & 9.6 & 8.7 & 8.6 & 8.5 \\
\hline Electronic Parts (BMS) & 5.5 & 5.0 & 4.8 & 4.7 \\
\hline
\end{tabular}


Table 40 Material composition of Li-ion batteries in Class 8 day-cab trucks (EV) (\%)

\begin{tabular}{|c|c|c|c|}
\hline \multirow{2}{*}{ Materials } & \multicolumn{3}{|c|}{ Material Composition (wt.\%) } \\
\cline { 2 - 4 } & NMC811 & NMC622 & NMC532 \\
\hline Cathode (active material) & 26.2 & 29.1 & 31.3 \\
\hline Graphite/Carbon Anode & 18.2 & 17.2 & 16.6 \\
\hline Silicon & 0.0 & 0.0 & 0.0 \\
\hline Binder (PVDF) & 0.9 & 0.9 & 1.0 \\
\hline Copper & 17.1 & 16.2 & 15.6 \\
\hline Wrought Aluminum & 22.9 & 22.1 & 21.4 \\
\hline Cast Aluminum & 0.0 & 0.0 & 0.0 \\
\hline LiPF & 1.3 & 1.3 & 1.3 \\
\hline Ethylene Carbonate & 3.7 & 3.7 & 3.7 \\
\hline Dimethyl Carbonate & 3.7 & 3.7 & 3.7 \\
\hline PP & 1.4 & 1.4 & 1.3 \\
\hline PE & 0.4 & 0.4 & 0.4 \\
\hline PET & 0.2 & 0.2 & 0.2 \\
\hline Steel & 0.1 & 0.1 & 0.1 \\
\hline Thermal Insulation & 0.6 & 0.6 & 0.5 \\
\hline Glycol & 3.1 & 3.0 & 2.9 \\
\hline Electronic Parts (BMS) & 0.2 & 0.2 & 0.2 \\
\hline
\end{tabular}

Table 41 Material composition of Li-ion batteries in Class 8 day-cab trucks (FCV) (\%)

\begin{tabular}{|c|c|c|c|c|}
\hline \multirow{2}{*}{ Materials } & \multicolumn{4}{|c|}{ Material Composition (wt.\%) } \\
\cline { 2 - 4 } & NMC811 & NMC622 & NMC532 & NMC111 \\
\hline Cathode (active material) & 13.7 & 15.4 & 16.9 & 17.2 \\
\hline Graphite/Carbon Anode & 9.9 & 9.5 & 9.3 & 9.1 \\
\hline Silicon & 0.0 & 0.0 & 0.0 & 0.0 \\
\hline Binder (PVDF) & 0.5 & 0.5 & 0.5 & 0.5 \\
\hline Copper & 26.2 & 25.7 & 25.2 & 25.1 \\
\hline Wrought Aluminum & 26.8 & 26.3 & 25.9 & 25.8 \\
\hline Cast Aluminum & 0.0 & 0.0 & 0.0 & 0.0 \\
\hline LiPF $_{\text {Ethylene Carbonate }}$ & 1.1 & 1.1 & 1.1 & 1.1 \\
\hline Dimethyl Carbonate & 3.0 & 3.1 & 3.1 & 3.1 \\
\hline PP & 3.0 & 3.1 & 3.1 & 3.1 \\
\hline PE & 1.2 & 1.2 & 1.1 & 1.1 \\
\hline PET & 0.5 & 0.5 & 0.5 & 0.5 \\
\hline Steel & 0.3 & 0.3 & 0.3 & 0.3 \\
\hline Thermal Insulation & 0.6 & 0.6 & 0.6 & 0.6 \\
\hline Glycol & 1.8 & 1.7 & 1.7 & 1.7 \\
\hline Electronic Parts (BMS) & 7.3 & 6.9 & 6.7 & 6.7 \\
\hline
\end{tabular}


Table 42 Material composition of Li-ion batteries in Class 8 sleeper-cab trucks (HEV) (\%)

\begin{tabular}{|c|c|c|c|c|}
\hline \multirow{2}{*}{ Materials } & \multicolumn{4}{|c|}{ Material Composition (wt.\%) } \\
\cline { 2 - 4 } & NMC811 & NMC622 & NMC532 & NMC111 \\
\hline Cathode (active material) & 12.5 & 13.3 & 14.6 & 14.9 \\
\hline Graphite/Carbon Anode & 9.2 & 8.3 & 8.2 & 8.0 \\
\hline Silicon & 0.0 & 0.0 & 0.0 & 0.0 \\
\hline Binder (PVDF) & 0.4 & 0.4 & 0.5 & 0.5 \\
\hline Copper & 27.0 & 25.1 & 24.6 & 24.7 \\
\hline Wrought Aluminum & 24.4 & 28.2 & 27.8 & 27.7 \\
\hline Cast Aluminum & 0.0 & 0.0 & 0.0 & 0.0 \\
\hline LiPF & 1.0 & 1.0 & 1.0 & 1.0 \\
\hline Ethylene Carbonate & 2.9 & 2.8 & 2.8 & 2.8 \\
\hline Dimethyl Carbonate & 2.9 & 2.8 & 2.8 & 2.8 \\
\hline PP & 1.2 & 1.2 & 1.1 & 1.1 \\
\hline PE & 0.6 & 0.5 & 0.5 & 0.5 \\
\hline PET & 0.3 & 0.3 & 0.3 & 0.3 \\
\hline Steel & 0.7 & 0.6 & 0.6 & 0.6 \\
\hline Thermal Insulation & 1.7 & 1.7 & 1.7 & 1.7 \\
\hline Glycol & 9.6 & 8.7 & 8.6 & 8.5 \\
\hline Electronic Parts (BMS) & 5.5 & 5.0 & 4.8 & 4.7 \\
\hline
\end{tabular}

Table 43 Material composition of Li-ion batteries in Class 8 sleeper-cab trucks (EV) (\%)

\begin{tabular}{|c|c|c|c|}
\hline \multirow{2}{*}{ Materials } & \multicolumn{3}{|c|}{ Material Composition (wt.\%) } \\
\cline { 2 - 4 } & NMC811 & NMC622 & NMC532 \\
\hline Cathode (active material) & 28.2 & 31.2 & 33.4 \\
\hline Graphite/Carbon Anode & 19.4 & 18.3 & 17.6 \\
\hline Silicon & 0.0 & 0.0 & 0.0 \\
\hline Binder (PVDF) & 1.0 & 1.0 & 1.0 \\
\hline Copper & 17.1 & 16.1 & 15.4 \\
\hline Wrought Aluminum & 19.9 & 19.1 & 18.5 \\
\hline Cast Aluminum & 0.0 & 0.0 & 0.0 \\
\hline LiPF $_{6}$ & 1.4 & 1.4 & 1.4 \\
\hline Ethylene Carbonate & 3.9 & 3.9 & 3.9 \\
\hline Dimethyl Carbonate & 3.9 & 3.9 & 3.9 \\
\hline PP & 1.5 & 1.4 & 1.4 \\
\hline PE & 0.4 & 0.4 & 0.4 \\
\hline PET & 0.2 & 0.2 & 0.2 \\
\hline Steel & 0.1 & 0.1 & 0.1 \\
\hline Thermal Insulation & 0.5 & 0.5 & 0.5 \\
\hline Glycol & 2.4 & 2.3 & 2.2 \\
\hline Electronic Parts (BMS) & 0.1 & 0.1 & 0.1 \\
\hline
\end{tabular}


Table 44 Material composition of Li-ion batteries in Class 8 sleeper-cab trucks (FCV) (\%)

\begin{tabular}{|c|c|c|c|c|}
\hline \multirow{2}{*}{ Materials } & \multicolumn{4}{|c|}{ Material Composition (wt.\%) } \\
\cline { 2 - 4 } & NMC811 & NMC622 & NMC532 & NMC111 \\
\hline Cathode (active material) & 12.9 & 14.5 & 15.9 & 16.2 \\
\hline Graphite/Carbon Anode & 9.3 & 8.9 & 8.8 & 8.6 \\
\hline Silicon & 0.0 & 0.0 & 0.0 & 0.0 \\
\hline Binder (PVDF) & 0.5 & 0.5 & 0.5 & 0.5 \\
\hline Copper & 26.8 & 26.4 & 25.8 & 25.9 \\
\hline Wrought Aluminum & 27.2 & 26.9 & 26.4 & 26.3 \\
\hline Cast Aluminum & 0.0 & 0.0 & 0.0 & 0.0 \\
\hline LiPF & 1.0 & 1.1 & 1.1 & 1.1 \\
\hline Ethylene Carbonate & 2.9 & 3.0 & 3.0 & 3.1 \\
\hline Dimethyl Carbonate & 2.9 & 3.0 & 3.0 & 3.1 \\
\hline PP & 1.2 & 1.2 & 1.2 & 1.2 \\
\hline PE & 0.5 & 0.5 & 0.5 & 0.5 \\
\hline PET & 0.3 & 0.3 & 0.3 & 0.3 \\
\hline Steel & 0.6 & 0.6 & 0.6 & 0.6 \\
\hline Thermal Insulation & 1.8 & 1.8 & 1.7 & 1.7 \\
\hline Glycol & 7.5 & 7.2 & 7.0 & 6.9 \\
\hline Electronic Parts (BMS) & 4.4 & 4.2 & 4.0 & 4.0 \\
\hline
\end{tabular}

Regarding Pb-acid batteries, the number of these batteries needed for various MHDVs is taken from literature (Interstate Batteries, 2021; Tomic et al., 2014) and provided in Table 45. Briefly, all MHDVs are assumed to use at least one $\mathrm{Pb}$-acid battery for initial startup requirement, as per literature (Interstate Batteries, 2021; Tomic et al., 2014), with more of these batteries employed in ICEV and HEV MHDVs to meet accessory loads. Based on the abovementioned information and other inputs, battery material composition (extended from the GREET $^{\circledR}$ model for LDVs) is provided in Table 46. Battery weights (for all batteries) are obtained for chosen MHDVs from literature for Pb-acid batteries (Interstate Batteries, 2021) and from BatPaC 4.0 for Li-ion batteries and are given in Tables 47-49.

Table 45 Number of Pb-acid batteries used for MHDVs with different propulsion technologies

\begin{tabular}{|c|c|c|c|c|}
\hline Type of MHDV & ICEV & HEV & EV & FCV \\
\hline Class 6 PnD & 2 & 2 & 1 & 1 \\
\hline Class 8 Day-cab & 3 & 2 & 1 & 1 \\
\hline Class 8 Sleeper-cab & 4 & 3 & 1 & 1 \\
\hline Weight of 1 Pb-acid battery: 69 lbs. (Interstate Batteries, 2021) \\
\hline
\end{tabular}


Table 46 Material composition of Pb-acid batteries in MHDVs

\begin{tabular}{|c|c|}
\hline Materials & Material Composition (wt.\%) \\
\hline PP & 6.1 \\
\hline Lead & 69.0 \\
\hline Sulfuric Acid & 7.9 \\
\hline Fiberglass & 2.1 \\
\hline Water & 14.1 \\
\hline Others & 0.8 \\
\hline
\end{tabular}

Table 47 Battery weight for Class 6 PnD trucks (lbs.)

\begin{tabular}{|c|c|c|c|c|c|}
\hline Battery Type & Battery Chemistry & ICEV & HEV & EV & FCV \\
\hline \multirow{3}{*}{ Pb-acid } & & 138 & 138 & 69 & 69 \\
\hline \multirow{3}{*}{ Li-ion } & NMC811 & N/A & 125 & 3,554 & 141 \\
\cline { 2 - 6 } & NMC622 & N/A & 131 & 3,729 & 147 \\
\cline { 2 - 6 } & NMC532 N/A & 136 & 3,945 & 153 \\
\cline { 2 - 6 } & NMC111 N/A & 137 & N/A & 155 \\
\hline N/A = Not applicable & N & N & \multicolumn{4}{|l}{} \\
\hline
\end{tabular}

Table 48 Battery weight for Class 8 day-cab trucks (lbs.)

\begin{tabular}{|c|c|c|c|c|c|}
\hline Battery Type & Battery Chemistry & ICEV & HEV & EV & FCV \\
\hline Pb-acid & & 207 & 138 & 69 & 69 \\
\hline \multirow{3}{*}{ Li-ion } & NMC811 & N/A & 155 & 9,667 & 203 \\
\cline { 2 - 6 } & NMC622 & N/A & 172 & 10,243 & 212 \\
\cline { 2 - 6 } & NMC532 & N/A & 179 & 10,928 & 222 \\
\cline { 2 - 6 } & NMC111 N/A & 182 & N/A & 226 \\
\hline N/A = Not applicable & N & \multicolumn{4}{|l}{} \\
\hline
\end{tabular}

Table 49 Battery weight for Class 8 sleeper-cab trucks (lbs.)

\begin{tabular}{|c|c|c|c|c|c|}
\hline Battery Type & Battery Chemistry & ICEV & HEV & EV & FCV \\
\hline Pb-acid & & 276 & 207 & 69 & 69 \\
\hline \multirow{3}{*}{ Li-ion } & NMC811 & N/A & 155 & 16,030 & 194 \\
\cline { 2 - 6 } & NMC622 & N/A & 172 & 17,039 & 203 \\
\cline { 2 - 6 } & NMC532 & N/A & 179 & 18,229 & 212 \\
\cline { 2 - 6 } & NMC111 N/A & 182 & N/A & 215 \\
\hline N/A = Not applicable & N & \multicolumn{4}{l}{} \\
\hline
\end{tabular}




\subsection{Battery Replacement and Recycling}

A critical factor in determining battery-related energy use and emissions over the lifetime of a MHDV is the number of times it has to be replaced in this duration. For all the MHDVs considered in this study, this depends on the nature of batteries employed (related to the propulsion technology used) and the distance traveled by them between two battery replacements.

Among the considered battery technologies, $\mathrm{Pb}$-acid batteries present the highest degree of certainty given the highly mature state of this technology. These batteries are typically replaced every four years for freight trucks, irrespective of the propulsion technology employed (Lowell, 2018). Hence, the battery replacement interval for Pb-acid batteries in MHDVs is obtained by multiplying this duration with their respective annual distance traveled, as provided by the U.S. Transportation Energy Data Book 2021 (Davis \& Boundy, 2021). Note that users can change this replacement schedule by modifying the number of $\mathrm{Pb}$-acid battery replacements for each of the considered MHDVs. Further, Pb-acid batteries enjoy high recycling rates ( 99\%) and use a high amount of recycled lead and plastic content (Illinois Sustainable Technology Center \& U.S. EPA Office of Solid Waste, 2015; U.S. EPA, 2020) — an aspect that is also considered earlier in the GREET $^{\circledR}$ model for LDVs (Argonne National Laboratory, 2020; Burnham, 2012; Burnham et al., 2006) and is extended here to MHDVs.

In contrast to $\mathrm{Pb}$-acid, there is less certainty for Li-ion battery replacement, which is mainly due to the limited amount of publicly available research data on the performance of these batteries in freight trucks. However, a few studies suggest that EV MHDVs will require Li-ion batteries to be replaced anywhere around 400,000-500,000 miles (Sen et al., 2017, 2019). Hence, the default assumption here is that Li-ion batteries will last for the entire lifetime of Class $6 \mathrm{EV}$ MHDVs but will be replaced once over the total lifetime of Class 8 EV MHDVs (day-cab and sleeper-cab). Users are provided the option to modify this assumption and provide the desired number of replacements for these batteries.

\subsection{Fuel Stack Replacement}

Similar to the case of batteries, there is limited information on the ability of fuel stacks to last over the entire lifetime of MHDVs, especially for Class 8 trucks. Nevertheless, the user is provided the option to account for any replacement in fuel-cell stacks over the lifetime of all chosen MHDVs and assess its effect on the impacts of fuel-cell MHDVs over their vehicle-cycle and life-cycle. The default option chosen in this study is no replacement of fuel-cell stacks over the lifetime of all fuel-cell MHDVs.

\subsection{Replacements of Components: Tire, Fluids, Fuel Stacks, and Others}

Apart from batteries and fuel-cell stacks, other subsystems/individual parts are also replaced during the lifetime of a freight truck. Here, four such parts/subsystems are considered:

tires, fluids, engine oil filters, and windshield wiper blades. Since the number of replacements for 
all these parts depends on the total lifetime of MHDVs, the total lifetime is considered as 300,000 miles for Class 6 PnD trucks (Clinton, 2015; Davis \& Boundy, 2021; Penske Used Trucks, 2021) and 1 million miles for Class 8 (day-cab and sleeper-cab) trucks (Marcinkoski et al., 2019; U.S. DOE, 2013).

Unlike LDVs, the tires used in MHDVs are of three types: (a) steer tires; (b) drive tires; and (c) trailer tires (used for trailers fitted to Class 8 truck tractors). This study assumes different lifetimes for these three sets of tires for the chosen truck options based on industry literature, as shown in Table 50. These lifetimes (in terms of replacements) are coupled with the tire material composition - assumed to be the same as that for LDVs in GREET $^{\circledR}$ at $67 \%$ rubber and 33\% steel (Argonne National Laboratory, 2020; Burnham, 2012; Burnham et al., 2006) - to obtain the total use of these materials for tires over the MHDV lifetime. Like for LDVs, the last set of tires (of either type) are considered to be scrapped with none of the tires being reused for any truck due to safety concerns.

Table 50 Lifetime of MHDV tires

\begin{tabular}{|c|c|c|c|c|}
\hline \multirow{2}{*}{ Type of MHDV } & \multicolumn{3}{|c|}{ Lifetime (miles) } & \multirow{2}{*}{ References } \\
\cline { 2 - 4 } & Steer Tires & Drive Tires & Trailer Tires & \\
\hline Class 6 PnD & 125,000 & 200,000 & \\
Class 8 Day-cab & 125,000 & 275,000 & 95,000 & \multirow{2}{*}{ (Kilcarr, 2006) } \\
\hline Class 8 Sleeper-cab & 125,000 & 275,000 & 95,000 & \\
\hline
\end{tabular}

Multiple fluids are used in MHDVs (including trailers) for routine maintenance at varying intervals. Several assumptions have been made about the lifetime of these fluids for MHDVs across various propulsion technologies, based on existing literature - these assumptions are provided in Tables 51-52. Additional assumptions about these fluids, including their individual material composition, are extended from Argonne's previous work on GREET ${ }^{\circledR}$ for LDVs (Argonne National Laboratory, 2020; Burnham, 2012; Burnham et al., 2006) and are given in Table 53. In addition, the mass of fluids used for different MHDVs are provided in Tables 54-57. For engine oil filters (used in ICEV and HEV MHDVs) and windshield wiper blades, their respective lifetimes (in terms of years and/or distance traveled) are given in Table 58. 
Table 51 Lifetime of MHDV fluids (miles)

\begin{tabular}{|c|c|c|c|c|}
\hline \multirow[b]{2}{*}{ Type of Fluid } & \multicolumn{3}{|c|}{ Type of MHDV (lifetime in miles) } & \multirow[b]{2}{*}{ References } \\
\hline & $\begin{array}{c}\text { Class } 6 \\
\text { PnD }\end{array}$ & $\begin{array}{l}\text { Class } 8 \text { Day- } \\
\text { cab }\end{array}$ & $\begin{array}{c}\begin{array}{c}\text { Class 8 Sleeper- } \\
\text { cab }\end{array} \\
\end{array}$ & \\
\hline Engine Oil & 30,000 & 50,000 & 50,000 & (Cummins, 2021) \\
\hline Steer Axle Lubricant & 25,000 & 25,000 & 25,000 & \multirow{5}{*}{$\begin{array}{l}\text { (Dana Spicer, } \\
\text { 2019) }\end{array}$} \\
\hline Drive Axle Lubricant & 500,000 & 500,000 & 500,000 & \\
\hline $\begin{array}{c}\text { Inter-axle Shaft/Driveshaft } \\
\text { Lubricant }\end{array}$ & 25,000 & $\begin{array}{l}350,000 \text { for } \\
1 \text { st cycle; } \\
100,000 \text { for } \\
\text { subsequent } \\
\text { cycles }\end{array}$ & $\begin{array}{l}350,000 \text { for } \\
1 \text { st cycle; } \\
100,000 \text { for } \\
\text { subsequent } \\
\text { cycles }\end{array}$ & \\
\hline $\begin{array}{c}\text { Lubricant: Wheel-ends at Steer } \\
\text { Axle }\end{array}$ & 500,000 & 500,000 & 500,000 & \\
\hline $\begin{array}{c}\text { Lubricant: Wheel-ends at Drive } \\
\text { Axle }\end{array}$ & 500,000 & 500,000 & 500,000 & \\
\hline Transmission Fluid & 75,000 & 500,000 & 500,000 & (Eaton, 2018) \\
\hline Engine/Powertrain Coolant & 150,000 & 932,057 & 932,057 & (Cummins \\
\hline Coolant Cleaner & \multicolumn{3}{|c|}{ Same as engine/powertrain coolant } & Filtration, 2021) \\
\hline $\begin{array}{c}\text { Windshield Fluid } \\
\text { (lifetime = } 6 \text { months) }\end{array}$ & 5,844 & 31,687 & 65,250 & $\begin{array}{l}\text { (Auto Zone Inc., } \\
\text { 2021) }\end{array}$ \\
\hline
\end{tabular}

Table 52 Lifetime of trailer fluids (miles)

\begin{tabular}{|c|c|l|}
\hline Type of Fluid & Lifetime (miles) & \multicolumn{1}{|c|}{ References } \\
\hline Trailer Axle Lubricant & 500,000 & (Dana Ltd., 2021; Dana Ltd. \& \\
\cline { 1 - 2 } Lubricant: Wheel-ends at Trailer Axle & 500,000 & Dana Spicer, 2021) \\
\hline
\end{tabular}


Table 53 Major assumptions regarding all vehicle fluids (including trailer)

\begin{tabular}{|c|c|}
\hline Type of Fluid & Key Assumptions \\
\hline Engine Oil & \multirow{5}{*}{$\begin{array}{l}\text { - Material composition, energy use, and emissions (on } \\
\text { per-lbs. basis) extended from similar fluids used in } \\
\text { LDVs in GREET } \\
\text { - Actual amount of use and replacement schedule } \\
\text { considered from literature (bottom-up approach) }\end{array}$} \\
\hline Power Steering Fluid & \\
\hline Brake Fluid & \\
\hline Windshield Fluid & \\
\hline Adhesives & \\
\hline Transmission Fluid & \multirow[b]{2}{*}{$\begin{array}{l}\text { - Material composition, energy use, and emissions (on } \\
\text { per-lbs. basis) extended from similar fluids used in } \\
\text { LDVs in GREET } \\
\text { - Actual amount of use and replacement schedule } \\
\text { considered from literature (bottom-up approach) } \\
\text { - Ratio of fluid use in HEV/EV/FCV MHDV to ICEV } \\
\text { MHDV assumed to be the same as that for fluid use in } \\
\text { HEV/EV/FCV LDV to ICEV LDV }\end{array}$} \\
\hline Engine/Powertrain Coolant & \\
\hline Steer Axle Lubricant & \multirow{8}{*}{$\begin{array}{l}\text { Material composition, energy use, and emissions (on } \\
\text { per-lbs. basis) assumed to be the same as that for } \\
\text { engine oil used in LDVs in GREET } \\
\text { - Actual amount of use and replacement schedule } \\
\text { considered from literature (bottom-up approach) }\end{array}$} \\
\hline Drive Axle Lubricant & \\
\hline Inter-axle Shaft/Driveshaft Lubricant & \\
\hline Lubricant: Wheel-ends at Steer Axle & \\
\hline Lubricant: Wheel-ends at Drive Axle & \\
\hline Coolant Cleaner & \\
\hline Trailer Axle Lubricant & \\
\hline Lubricant: Wheel-ends at Trailer Axle & \\
\hline
\end{tabular}

Table 54 Amount of fluids used per use cycle in ICEV MHDVs

\begin{tabular}{|c|c|c|c|}
\hline \multirow{2}{*}{ Type of Fluid } & \multicolumn{3}{|c|}{ Weight of Fluids Used (lbs.): ICEV } \\
\cline { 2 - 4 } & Class 6 PnD & Class 8 Day-cab & Class 8 Sleeper-cab \\
\hline Engine Oil & 33.7 & 92.2 & 92.2 \\
\hline Steer Axle Lubricant & 15.4 & 15.4 & 15.4 \\
\hline Drive Axle Lubricant & 12.9 & 45.2 & 45.2 \\
\hline Inter-axle Shaft/Driveshaft Lubricant & 30.9 & 30.9 & 30.9 \\
\hline Lubricant: Wheel-ends at Steer Axle & 19.0 & 19.0 & 19.0 \\
\hline Lubricant: Wheel-ends at Drive Axle & 19.0 & 38.0 & 38.0 \\
\hline Power Steering Fluid & 0.0 & 0.0 & 0.0 \\
\hline Brake Fluid & 0.0 & 0.0 & 0.0 \\
\hline Transmission Fluid & 16.9 & 14.1 & 14.1 \\
\hline Engine/Powertrain Coolant & 54.1 & 121.1 & 121.1 \\
\hline Coolant Cleaner & 55.1 & 55.1 & 55.1 \\
\hline Windshield Fluid & 15.9 & 15.9 & 15.9 \\
\hline Trailer Axle Lubricant & N/A & 45.2 & 35.2 \\
\hline Lubricant: Wheel-ends at Trailer Axle & N/A & 38.0 & \\
\hline N/A = Not applicable & \multicolumn{3}{|}{} \\
\hline
\end{tabular}


Table 55 Amount of fluids used per use cycle in HEV MHDVs

\begin{tabular}{|c|c|c|c|}
\hline \multirow{2}{*}{ Type of Fluid } & \multicolumn{3}{|c|}{ Weight of Fluids Used (lbs.): HEV } \\
\cline { 2 - 4 } & Class 6 PnD & Class 8 Day-cab & Class 8 Sleeper-cab \\
\hline Engine Oil & 33.7 & 92.2 & 92.2 \\
\hline Steer Axle Lubricant & 15.4 & 15.4 & 15.4 \\
\hline Drive Axle Lubricant & 12.9 & 45.2 & 45.2 \\
\hline Inter-axle Shaft/Driveshaft Lubricant & 30.9 & 30.9 & 30.9 \\
\hline Lubricant: Wheel-ends at Steer Axle & 19.0 & 19.0 & 19.0 \\
\hline Lubricant: Wheel-ends at Drive Axle & 19.0 & 38.0 & 38.0 \\
\hline Power Steering Fluid & 0.0 & 0.0 & 0.0 \\
\hline Brake Fluid & 0.0 & 0.0 & 0.0 \\
\hline Transmission Fluid & 5.2 & 2.2 & 2.2 \\
\hline Engine/Powertrain Coolant & 54.1 & 121.1 & 121.1 \\
\hline Coolant Cleaner & 55.1 & 55.1 & 55.1 \\
\hline Windshield Fluid & 15.9 & 15.9 & 15.9 \\
\hline Trailer Axle Lubricant & N/A & 45.2 & 45.2 \\
\hline Lubricant: Wheel-ends at Trailer Axle & N/A & 45.2 & 45.2 \\
\hline N/A = Not applicable & \multicolumn{3}{|}{} \\
\hline
\end{tabular}

Table 56 Amount of fluids used per cycle in EV MHDVs

\begin{tabular}{|c|c|c|c|}
\hline \multirow{2}{*}{ Type of Fluid } & \multicolumn{3}{|c|}{ Weight of Fluids Used (lbs.): EV } \\
\cline { 2 - 4 } & Class 6 PnD & Class 8 Day-cab & Class 8 Sleeper-cab \\
\hline Engine Oil & 0.0 & 0.0 & 0.0 \\
\hline Steer Axle Lubricant & 15.4 & 15.4 & 15.4 \\
\hline Drive Axle Lubricant & 12.9 & 45.2 & 45.2 \\
\hline Inter-axle Shaft/Driveshaft Lubricant & 30.9 & 30.9 & 30.9 \\
\hline Lubricant: Wheel-ends at Steer Axle & 19.0 & 19.0 & 19.0 \\
\hline Lubricant: Wheel-ends at Drive Axle & 19.0 & 38.0 & 38.0 \\
\hline Power Steering Fluid & 0.0 & 0.0 & 0.0 \\
\hline Brake Fluid & 0.0 & 0.0 & 0.0 \\
\hline Transmission Fluid & 5.2 & 2.2 & 2.2 \\
\hline Engine/Powertrain Coolant & 37.1 & 83.0 & 83.0 \\
\hline Coolant Cleaner & 37.8 & 37.8 & 37.8 \\
\hline Windshield Fluid & 15.9 & 15.9 & 15.9 \\
\hline Trailer Axle Lubricant & N/A & 45.2 & 45.2 \\
\hline Lubricant: Wheel-ends at Trailer Axle & N/A & 45.2 & 45.2 \\
\hline N/A = Not applicable & \multicolumn{2}{|}{} \\
\hline
\end{tabular}


Table 57 Amount of fluids used per cycle in FCV MHDVs

\begin{tabular}{|c|c|c|c|}
\hline \multirow{2}{*}{ Type of Fluid } & \multicolumn{3}{|c|}{ Weight of Fluids Used (lbs.): FCV } \\
\cline { 2 - 4 } & Class 6 PnD & Class 8 Day-cab & Class 8 Sleeper-cab \\
\hline Engine Oil & 0.0 & 0.0 & 0.0 \\
\hline Steer Axle Lubricant & 15.4 & 15.4 & 15.4 \\
\hline Drive Axle Lubricant & 12.9 & 45.2 & 45.2 \\
\hline Inter-axle Shaft/Driveshaft Lubricant & 30.9 & 30.9 & 30.9 \\
\hline Lubricant: Wheel-ends at Steer Axle & 19.0 & 19.0 & 19.0 \\
\hline Lubricant: Wheel-ends at Drive Axle & 19.0 & 38.0 & 38.0 \\
\hline Power Steering Fluid & 0.0 & 0.0 & 0.0 \\
\hline Brake Fluid & 0.0 & 0.0 & 0.0 \\
\hline Transmission Fluid & 5.2 & 2.2 & 2.2 \\
\hline Engine/Powertrain Coolant & 37.1 & 83.0 & 83.0 \\
\hline Coolant Cleaner & 37.8 & 37.8 & 37.8 \\
\hline Windshield Fluid & 15.9 & 15.9 & 45.9 \\
\hline Trailer Axle Lubricant & N/A & 45.2 & 45.2 \\
\hline Lubricant: Wheel-ends at Trailer Axle & N/A & 45.2 & \\
\hline N/A = Not applicable & \multicolumn{2}{|}{} \\
\hline
\end{tabular}

Table 58 Lifetime of frequently replaced MHDV parts (years/miles)

\begin{tabular}{|c|c|c|}
\hline MHDV Parts & Lifetime (years/miles) & References \\
\hline Windshield Wiper Blades & 1 year & (Auto Zone, 2021) \\
\hline $\begin{array}{c}\text { Engine Oil Filters } \\
\text { (changed along with engine oil) }\end{array}$ & Same as engine oil & (Cummins, 2021) \\
\hline
\end{tabular}

\subsection{Limitations}

In addition to the lack of vehicle inventory from a single source, there are also other limitations associated with this MHDV inventory development. The first is the extension of several parameters used for LDVs in GREET ${ }^{\circledR}$ to MHDVs examined here due to the lack of alternative data in our literature review. This includes the: (a) weight share of virgin and recycled content for different materials, such as steel, wrought aluminum, and cast aluminum; (b) energy use and emissions associated with various vehicle fluids, including those used specifically in MHDVs; (c) weight composition of different plastics in the average plastic used; and (d) material composition of traction motor, generator, electronic controller, vehicle fluids, and $\mathrm{Pb}$-acid battery. In addition, the lack of any inventory details for multiple materials, including those specifically used in MHDVs (such as wood, damask fiber, and niobium), as well as those used in MHDVs and LDVs (like titanium and chromium) in the GREET $^{\circledR}$ model, meant that energy and emission values associated with these elements is 0 , i.e., their contributions cannot be considered. Nevertheless, the small amount of use of these elements across all MHDVs means that these elements are not expected to drastically change the vehicle-cycle energy use and emissions for the considered MHDVs. 


\section{VEHICLE ASSEMBLY, DISPOSAL, AND RECYCLING}

This analysis utilizes the past data on energy use and emissions associated with the assembly, painting, disposal, and recycling processes for the MHDVs (the entire Class $6 \mathrm{PnD}$ truck and both the tractor and trailer for Class 8 trucks). Hence, barring the recycling of MHDVs, energy consumption and emissions of various constituent ADR processes are assumed to be the same as for these processes in the GREET ${ }^{\circledR}$ model for LDVs (Argonne National Laboratory, 2020; Burnham, 2012; Burnham et al., 2006). For vehicle recycling, the amount of energy use and emissions is scaled-up from the LDV model to fit the MHDV mass. Like for LDVs, this energy use (or associated emissions) does not include any of the material recovery process or combustion processes associated with energy recovery; instead, energy use of materials that are recycled (reprocessed) for use in MHDVs is considered separately within the GREET ${ }^{\circledR}$ model.

Regarding battery assembly and testing of both $\mathrm{Pb}$-acid batteries (on per-lb. basis) and Li-ion batteries (on per-kWh basis), data for their energy use and emissions are extended from the GREET ${ }^{\circledR}$ model for LDVs (Argonne National Laboratory, 2020; Burnham, 2012; Burnham et al., 2006). Table 59 shows the amount of energy consumed for different constituent ADR processes for trucks, trailers, and batteries, along with their corresponding units.

Table 59 Energy use associated with vehicle and battery ADR processes

\begin{tabular}{|c|r|c|}
\hline Constituent ADR Process & Energy Consumed & \multirow{2}{*}{ Unit } \\
\hline Paint Production & 0.287 & \multirow{3}{*}{ mmBtu per } \\
\hline Painting & 2.759 & \multirow{2}{*}{ vehicle/trailer } \\
\hline HVAC and Lighting & 0.99 & \\
\hline Heating & 2.982 & \\
\hline Material Handling & 0.205 & \\
\hline Welding & 0.273 & \\
\hline Compressed Air & 0.409 & mmBtu per lb. \\
\hline Disposal/Recycling & $0.00047 \times$ weight \\
& (weight = weight of MHDV/trailer) & mmBtu per $\mathrm{kWh}$ \\
\hline Pb-acid Battery Assembly & 2.300 & \\
\hline Li-ion Battery Assembly & 0.161 & \\
\hline
\end{tabular}




\section{GREET2 MODEL STRUCTURE EXPANSION FOR MHDVS}

The following sections introduce the additional working sheets incorporated in the updated version of the GREET2 model. The sheets are all related specifically to MHDV profiles and auxiliary calculation processes. In general, the sheets are modeled using the same basis as the LDV sheets to retain coherence for users.

\subsection{MHDV_Inputs Sheet}

This sheet is separated into nine sections:

1. Selection of truck types for simulation (as input).

2. Specification of total truck weight.

3. Truck battery and fluids weight.

4. Key input parameters for truck components: body, powertrain system, transmission system, chassis, traction motor, generator, electronic controller, and fuel-cell auxiliary system.

5. Key input parameters for batteries, fuel stacks, and hydrogen tanks.

6. Key input parameters for fluids and repeatedly replaced components.

7. GREET $^{\circledR}$ default key assumptions for truck/trailer ADR.

8. Lifetime vehicle miles traveled of MHDVs and trailers.

9. Trailers.

Like for LDVs, this sheet provides key variables for vehicle-cycle scenarios and specifies important parametric assumptions for MHDVs and their components for subsequent calculations in GREET2 (regarding total energy use and various emissions).

In the MHDV_Inputs sheet, the first section (Section 1) allows the user to specify the truck option (Class $6 \mathrm{PnD}$, Class 8 day-cab, or Class 8 sleeper-cab truck), for which energy use and emissions are to be calculated. Next, Section 2 inputs the total weight of the concerned truck to be simulated (taken from the individual sheets for each chosen truck option, described in Section 5.3). Similarly, Section 3 takes the weight of Pb-acid and Li-ion batteries for each propulsion technology as inputs from the individual truck option-based sheets (see Section 5.3).

In Section 4, the weight of all MHDV components (excluding batteries, fluids, and fuel) is provided for each propulsion technology for the specific chosen MHDV. This section also provides the power sizing of fuel-cell stack (in $\mathrm{kW}$ ), followed by its weight-to-power ratio (lbs./kW) and the overall weight of fuel-cell stacks and auxiliary components (hydrogen tanks). For all MHDVs, this section gives the detailed break-up of weight and weight share (wt.\%) for all the component categories included in this section. Additionally, it gives the values for the number of replacements, as well as the number of components, used per use-cycle (during operation) for tires, windshield wiper blades, and engine oil filters, along with the weight of vehicle tires. 
Section 5 details key input parameters for batteries, including the choice of Li-ion battery cathode chemistry (NMC811, NMC622, NMC532, and NMC111), the size of battery (energy/power) for various propulsion technologies, the number of battery replacements over MHDV lifetime, and the value of specific power and energy for Li-ion batteries for various MHDVs. Additionally, this section gives the user the choice to select pressure ( 700 bar or 350 bar) for the hydrogen tank of FCV trucks for the concerned truck option. The section also allows for specifying the number of fuel-cell stack replacements during the lifetime of FCV MHDVs (with the default value being 0 ).

Section 6 allows the user to focus on key inputs for fluids, including the number of replacements for various fluids as well as the ratio of waste-to-product for their disposal. Section 7 gives the default key assumptions for energy use during battery assembly (for various batteries used in trucks) and during the vehicle assembly, painting, disposal, and recycling (ADR) phase. Subsequently, Section 8 provides the lifetime of the truck in terms of miles (and not years).

Finally, Section 9 represents the important focal point of the difference between GREET ${ }^{\circledR}$ sheets for LDVs and freight trucks, for this section contains inputs on trailers used in Class 8 trucks. Apart from the number of trailer tires and the frequency of their replacement over a truck's lifetime, it also provides data on trailer tire weight, trailer vehicle fluids (quantity used per cycle and number of replacement cycles), and trailer weight composition (overall weight and weight share of different trailer parts, namely, trailer body, chassis, and auxiliary parts). In addition, this section provides energy use values for ADR processes associated with trailers.

\subsection{MHDV_Mat_Parameters Sheet}

This sheet is separated into three sections:

1. Material composition for truck components.

2. Battery material composition.

3. Material composition for trailer components.

For all the three sections of MHDV_Mat_Parameters sheet, the values depend on the type of MHDV (Class 6 PnD, Class 8 day-cab, or Class 8 sleeper-cab) chosen. Section 1 shows the material break-up of all component systems listed in Table 2, as well as the aggregate material composition of the concerned MHDV. In addition, it also gives the material composition of tires (extended from LDVs) and individual parts that are frequently replaced (windshield wiper blades and engine oil filters). Section 2 gives details on the material composition of $\mathrm{Pb}$-acid and Li-ion batteries (inclusive of all the Li-ion battery chemistries). Lastly, Section 3 gives information on the material composition of the trailer component groups/systems and of the entire trailer. 


\subsection{Class 6 PnD Trucks, Class 8 Day-cab Trucks, and Class 8 Sleeper-cab Trucks Sheets}

These three sheets are organized on similar lines and contain all the inputs for their respective MHDVs. These inputs are then used in MHDV_Inputs and MHDV_Mat_Parameters sheets, based on the MHDV chosen in MHDV_Inputs sheet.

\subsection{MHDV_Fluids Sheet}

This worksheet consists of the following five sections:

1. Key input parameters: The values in this section are derived from the MHDV_Inputs sheet and then manipulated/processed to calculate the energy use and emissions associated with vehicle fluids used in MHDVs (excluding trailers).

2. Shares of combustion processes for each stage: These are used to calculate emissions.

3. Calculation of energy consumption and emissions for each stage: Here, GREET2 calculates the energy use and emissions for each individual vehicle fluid, considering the fuel use by type, combustion technology, energy efficiency, and other aspects.

4. Summary of energy consumption and emissions related to fluids: This involves significant parameters that are used later for per-vehicle lifetime calculations.

5. Per-vehicle lifetime energy consumption and emissions of fluids: Here, energy use and emissions are calculated on per-vehicle lifetime basis and are subsequently used to determine vehicle-cycle energy use and emissions in other sheets.

Here, energy use and emission calculations are undertaken for multiple fluids that are used in MHDVs. These include engine oil, powertrain coolant, coolant cleaner, windshield fluid, power steering fluid, brake fluid, transmission fluid, adhesives, and lubrication oil (used in steer and drive axles, inter-axle shaft, driveshaft, and wheel-ends at steer and drive axles). The weight of each fluid (on per-vehicle basis) and the number of replacements per MHDV lifetime are already defined in the MHDV_Inputs sheet, while for each fluid, the waste-to-product ratio is taken from the MHDV_Inputs sheet (which is in turn derived from the concerned MHDV sheet, described in Section 5.3). These waste-to-product ratio values are in turn extended from LDVs to MHDVs.

\subsection{MHDV_Trailer_Fluids Sheet}

This worksheet consists of the following five sections:

1. Key input parameters: The values in this section are derived from the MHDV_Inputs sheet and then manipulated/processed to calculate energy use and emissions associated with the fluids used in trailers. 
2. Shares of the combustion processes for each stage: These are used to calculate emissions.

3. Calculation of energy consumption and emissions for each stage: GREET2 calculates the energy use and emissions for each individual process, considering the fuel use by type, combustion technology, energy efficiency, and other aspects.

4. Summary of energy consumption and emissions related to fluids: This involves key parameters that are used for per-vehicle lifetime calculations.

5. Per-vehicle lifetime energy consumption and emissions of fluids: Here, energy use and emissions are calculated on per-vehicle lifetime basis and are subsequently used for vehicle-cycle-related calculations in other sheets.

Here, energy use and emission calculations are undertaken for lubrication oils used in trailer axles and trailer wheel-ends.

\subsection{MHDV_ADR Sheet}

This worksheet, modeled off the Vehi_ADR sheet for LDVs, consists of four sections:

1. Key input parameters: This section provides the share of different types for various materials, including the extent of recycled material content, that are used in different MHDVs, extending these shares from LDVs.

2. Shares of combustion processes for each stage: These are used to calculate emissions.

3. Calculations of energy consumption and emissions for each stage: This is done for individual stages associated with truck assembly, painting, disposal, and recycling, keeping in mind factors associated with fuel use by type, combustion technology, and energy efficiency.

4. Summary of energy consumption and emissions for ADR processes on per-vehicle basis: This is used in subsequent vehicle-cycle calculations in other GREET2 sheets.

\subsection{MHDV_Trailer_ADR Sheet}

This worksheet is modeled off the MHDV_ADR sheet (described in Section 5.6) with the exact same sections as in MHDV_ADR sheet (coupled with the descriptions). The same key input parameters are used as those for LDVs, considering the paucity of data availability on this aspect for trailers used in Class 8 trucks. 


\subsection{MHDV_Battery_Sum Sheet}

This worksheet, modeled off the Battery_Sum sheet for LDVs, consists of three sections:

1. Key input parameters: Input values from MHDV_Inputs and MHDV_Mat_Parameters sheets are taken here for further processing.

2. Calculation of energy consumption and emissions for each battery type on per-vehicle lifetime: Energy use and emissions of each battery ( $\mathrm{Pb}$-acid and Li-ion) for different propulsion technologies are calculated using their respective material composition and material-based energy use and emissions from the Mat_Sum sheet.

3. Summary of energy consumption and emissions: Calculations on battery-related energy use and emissions are summarized here and used subsequently for vehiclecycle-related calculations in other GREET2 sheets. While the type of battery used in HEV and FCV MHDVs, along with peak battery output, number of battery replacements, specific power of battery, and their weight are defined in the MHDV_Inputs sheet, the material composition of batteries is given in the MHDV_Mat_Parameters sheet.

\subsection{MHDV_Comp_Sum Sheet}

This worksheet is modeled off the Vehi_Comp_Sum sheet (used for LDVs) and consists of three sections:

1. Key input parameters: The parameters are derived from MHDV_Inputs and MHDV_Mat_Parameters sheet and are processed further here.

2. Summary of energy consumption and emissions for vehicle materials on per-vehicle lifetime: The weight of each material in each vehicle component system is given along with the energy used and emissions for all components/systems in each MHDV over the entire MHDV lifetime.

3. Summary of energy consumption and emissions by vehicle component (per-vehicle lifetime): Energy use and emissions are disaggregated by each component system in the concerned MHDV over its lifetime.

\subsection{MHDV_Trailer_Comp_Sum Sheet}

This worksheet, similar to the MHDV_Comp_Sum sheet for MHDVs, consists of two sections:

1. Key input parameters: These input values are taken from MHDV_Inputs and MHDV_Mat_Parameters sheet and are processed further here. 
2. Summary of energy consumption and emissions for trailer materials (per-trailer lifetime): Here, energy use and emissions are disaggregated by each trailer component system and then totaled to obtain the overall value for the entire trailer lifetime (assumed to be the same as MHDV lifetime).

\subsection{MHDV_Sum Sheet}

This worksheet, modeled off the Vehi_Sum sheet for LDVs, consists of three sections:

1. Summary of energy consumption and emissions per vehicle lifetime: Energy use and emissions are displayed for MHDV truck components, ADR, batteries, fluids, and trailers, and these are totaled to obtain the overall vehicle-cycle energy use and emissions for all MHDVs.

2. Summary of energy consumption and emissions of vehicle-cycle per mile: Here, vehicle-cycle energy use and emissions for each MHDV are converted to per-mile results.

3. Vehicle-cycle energy and emissions changes: Vehicle-cycle energy use and emissions are shown as percentages relative to ICEV.

\subsection{MHDV_TEC_Results Sheet}

This worksheet consists of two sections:

1. Well-to-pump, vehicle-cycle, and vehicle-operation energy use and emissions: Here, fuel-cycle (well-to-pump) and vehicle-operation values are obtained from GREET1 (imported in GREET1_Import_Export sheet in the GREET2 workbook), while vehicle-cycle results are calculated here and added up to estimate the total life-cycle results for each MHDV.

2. Well-to-pump, vehicle-cycle, and vehicle-operation energy and emissions changes: Here, total life-cycle energy use and emissions of different propulsion technologies are shown as percentages relative to the conventional diesel-based ICEV MHDV. 


\section{REFERENCES}

4 State Trucks. (2021). 4 State Trucks. 4 State Trucks. https://www.4statetrucks.com/

75 Chrome Shop. (2021). 75 Chrome Shop: Home. 75 Chrome Shop. https://www.75chromeshop.com/

Argonne National Laboratory. (2018). BatPaC: A lithium-ion battery performance and cost model for electric-drive vehicles (version 4.0). https://www.anl.gov/cse/batpac-modelsoftware

Argonne National Laboratory. (2020). The Greenhouse gases, Regulated Emissions, and Energy use in Transportation model $\left(G_{R E E T^{\circledR}}\right)$. Argonne National Laboratory Energy Systems Division. https://greet.es.anl.gov/greet.models

Argonne National Laboratory. (2021). Autonomie. https://www.autonomie.net/index.html

Auto Zone. (2021). How long do windshield wipers last? Auto Zone Inc. https://www.autozone.com/diy/wipers/how-long-do-windshield-wipers-last

Auto Zone Inc. (2021). Auto Zone - Home. Auto Zone Inc. https://www.autozone.com/

Bicer, Y., \& Dincer, I. (2018). Life cycle environmental impact assessments and comparisons of alternative fuels for clean vehicles. Resources, Conservation and Recycling, 132, 141-157. https://doi.org/10.1016/j.resconrec.2018.01.036

Big Rig World. (2021). Big Rig World - Home. Big Rig World. https://bigrigworld.com/

Big Truck Hoods. (2021). Big Truck Hoods - Home. Big Truck Hoods. https://bigtruckhoods.com/

Burke, A., \& Sinha, A. K. (2020). Technology, sustainability, and marketing of battery electric and hydrogen fuel cell medium-duty and heavy-duty trucks and buses in 2020-2040: A research report from the national center for sustainable transportation. University of California, Davis and National Center for Sustainable Transportation. https://doi.org/10.7922/G2H993FJ

Burnham, A. (2012). Updated vehicle specifications in the GREET vehicle-cycle model. Center for Transportation Research, Argonne National Laboratory. https://greet.es.anl.gov/publication-update-veh-specs

Burnham, A., Wang, M., \& Yu, W. (2006). Development and applications of GREET 2.7 - The transportation vehicle-cycle model. Energy Systems Division, Argonne National Laboratory. https://greet.es.anl.gov/publication-lkldbrwj

Buy Truck Wheels. (2021). Buy Truck Wheels - Home. Buy Truck Wheels. https://buytruckwheels.com/

Cardone. (2019). Cardone - Home. Cardone. https://www.cardone.com/

Chassis King. (2021). Chassis King - Home. Chassis King. http://www.chassisking.com/ 
Clinton, P. (2015, November 11). Class 6 trucks oldest on road. HDT Truckinginfo. https://www.truckinginfo.com/132350/class-6-trucks-oldest-on-road

Cummins. (2021). Cummins. Cummins. https://www.cummins.com/

Cummins Filtration. (2021). Cummins Filtration - Home. Cummins. https://www.cumminsfiltration.com/homepage

Cunanan, C., Tran, M.-K., Lee, Y., Kwok, S., Leung, V., \& Fowler, M. (2021). A review of heavy-duty vehicle powertrain technologies: Diesel engine vehicles, battery electric vehicles, and hydrogen fuel cell electric vehicles. Clean Technologies, 3(2), 474-489. https://doi.org/10.3390/cleantechnol3020028

Daimler Trucks North America LLC. (2021). Freightliner trucks. Freightliner. https://freightliner.com/

Dana Ltd. (2021). Dana Aftermarket Media Library. Dana. http://media.spicerparts.com/

Dana Ltd., \& Dana Spicer. (2021). Dana Aftermarket - North America homepage. Dana. https://www.danaaftermarket.com/spicer

Dana Spicer. (2019). Spicer(R) axle, driveshaft, tire-pressure management systems, and wheelend systems: Specifications guide. Dana Spicer Drivetrain Products. http://global.dana.com/ /media/danacom/files/media-asset/commercial-vehicle/cvliterature/specguideupdatev01r03.pdf

Davis, S. C., \& Boundy, R. G. (2021). Transportation energy data book: Edition 39. Oak Ridge National Laboratory. https://tedb.ornl.gov/wp-content/uploads/2021/02/TEDB_Ed_39.pdf

Drivetrain America. (2021). Drivetrain America - Home. Drivetrain America. https://www.drivetrainamerica.com/

Eaton. (2014). Eaton Inforanger. Eaton (backed by Roadranger Support). http://www.inforanger.roadranger.com/index.aspx

Eaton. (2018). Eaton(R) lubrication TCMT0021 EN-US: Product specification manual. Eaton (backed by Roadranger Support).

https://www.eaton.com/ecm/groups/public/@pub/@eaton/@ roadranger/documents/content/ tcmt0021en-us.pdf

FinditParts Inc. (2021). FinditParts - Home. FinditParts. https://www.finditparts.com/

Fleet Truck Parts. (2021). Fleet truck parts. Fleet Truck Parts. https://www.fleettruckparts.com/

Forrest, K., Mac Kinnon, M., Tarroja, B., \& Samuelsen, S. (2020). Estimating the technical feasibility of fuel cell and battery electric vehicles for the medium and heavy duty sectors in California. Applied Energy, 276, 115439. https://doi.org/10.1016/j.apenergy.2020.115439

Gaines, L., Stodolsky, F., \& Cuenca, R. (1998). Lifecycle-analysis for heavy vehicles. Argonne National Laboratory. https://www.osti.gov/biblio/10731

Illinois Sustainable Technology Center, \& U.S. EPA Office of Solid Waste. (2015). Battery recycling: Battery recycling facts. https://guides.library.illinois.edu/battery-recycling/facts 
Interstate Batteries. (2021). Interstate batteries - Home. Interstate Batteries. https://www.interstatebatteries.com/

Islam, E. S., Vijayagopal, R., Kim, N., Moawad, A., Dupont, B., Nieto Prada, D., \& Rousseau, A. (2021). A detailed vehicle modeling \& simulation study quantifying energy consumption and cost reduction of advanced vehicle technologies through 2050. Argonne National Laboratory, ANL/ESD-21/10.

James, B., Houchins, C., \& Huya-Kouadio, J. (2021). Personal communication with Strategic Analysis. Argonne National Laboratory.

Joshi, A. (2020). Review of vehicle engine efficiency and emissions. SAE International Journal of Advanced and Current Practices in Mobility, 2(5), 2,479-2,507. https://doi.org/10.4271/2020-01-0352

Kilcarr, S. (2006, September 1). TIRES: One for all? FleetOwner. https://www.fleetowner.com/equipment/article/21662092/tires-one-for-all

Kluschke, P., Gnann, T., Plötz, P., \& Wietschel, M. (2019). Market diffusion of alternative fuels and powertrains in heavy-duty vehicles: A literature review. Energy Reports, 5, 1,010 1,024. https://www.sciencedirect.com/science/article/pii/S2352484719301167

Lowell, K. K. (2018). How often do you need to replace the batteries in a diesel truck? ItStillRuns. https://itstillruns.com/do-replace-batteries-diesel-truck-5825170.html

Machado, P. G., Teixeira, A. C. R., Collaço, F. M. A., \& Mouette, D. (2021). Review of life cycle greenhouse gases, air pollutant emissions and costs of road medium and heavy-duty trucks. Wiley Interdisciplinary Reviews: Energy and Environment, 10(4), e395. https://doi.org/10.1002/WENE.395

Marcinkoski, J., Vijayagopal, R., Adams, J., James, B., Kopasz, J., \& Ahluwalia, R. (2019). DOE Hydrogen and Fuel Cells Program, Record 19006: Hydrogen Class 8 long haul truck targets. U.S. Department of Energy. https://www.hydrogen.energy.gov/pdfs/19006_hydrogen_class8_long_haul_truck_targets.p df

Morgan Truck Body. (2021). Morgan truck body - Home. Morgan Truck Body. https://www.morgancorp.com/

Navistar Inc. (2021). International trucks - Home. International. https://www.internationaltrucks.com/

Osorio-Tejada, J. L., Llera-Sastresa, E., \& Scarpellini, S. (2017). A multi-criteria sustainability assessment for biodiesel and liquefied natural gas as alternative fuels in transport systems. Journal of Natural Gas Science and Engineering, 42, 169-186. https://doi.org/10.1016/j.jngse.2017.02.046

Penske Used Trucks. (2021). First-time buyer. Penske. https://www.penskeusedtrucks.com/buying-from-penske/first-time-buyer

Pradeep, S. A. S. A., Iyer, R. K., Kazan, H., \& Pilla, S. (2017). Automotive applications of plastics: Past, present and future. In M. Kutz (Ed.), Applied Plastics Engineering Handbook: Processing, Materials, and Applications (2nd ed., pp. 651-674). Elsevier. https://doi.org/10.1016/B978-0-323-39040-8.00031-6 
Ragatz, A., \& Thornton, M. (2016). Aerodynamic drag reduction technologies testing of heavyduty vocational vehicles and a dry van trailer. National Renewable Energy Laboratory. www.nrel.gov/publications.html

RitchieSpecs. (2018). RitchieSpecs . RitchieSpecs Equipment Specifications Ritchie Bros. Auctioneers. https://www.ritchiespecs.com/

Rodríguez, F., Muncrief, R., Delgado, O., \& Baldino, C. (2017). Market penetration of fuelefficiency technologies for heavy-duty vehicles in the European Union, the United States, and China. The International Council on Clean Transportation. https://theicct.org/sites/default/files/publications/HDV-market-penetration_ICCT_WhitePaper_050917_vF_corrected.pdf

SAF-Holland Group. (2021). SAF-Holland - Home. SAF-Holland Group. http://www.safholland.us/us/en/

Sen, B., Ercan, T., \& Tatari, O. (2017). Does a battery-electric truck make a difference? Life cycle emissions, costs, and externality analysis of alternative fuel-powered Class 8 heavyduty trucks in the United States. Journal of Cleaner Production, 141, 110-121. https://doi.org/10.1016/j.jclepro.2016.09.046

Sen, B., Ercan, T., Tatari, O., \& Zheng, Q. P. (2019). Robust Pareto optimal approach to sustainable heavy-duty truck fleet composition. Resources, Conservation and Recycling, 146, 502-513. https://doi.org/10.1016/J.RESCONREC.2019.03.042

STI Holdings Inc. (2012). Trailer parts catalog. Stoughton Trailers. https://www.stoughtontrailers.com/portals/0/documents/parts/parts-catalogs/Full Parts Catalog.pdf

STI Holdings Inc. (2021). Stoughton Trailers - Home. Stoughton Trailers. https://www.stoughtontrailers.com/

The Goodyear Tire \& Rubber Company. (2021). Goodyear - Home. Goodyear. https://www.goodyear.com/

Tomic, J., Toomey, L., Bloch-Rubin, T., \& Gallo, J.-B. (2014, August). Lithium-ion 6T battery technology-field testing in commercial trucks. Proceedings of the 2014 Ground Vehicle Systems Engineering and Technology Symposium (GVSETS). http://gvsets.ndiamich.org/documents/PM/2014/Lithium-Ion 6T Battery Technology-Field Testing in Commercial Trucks.pdf

Truck iD. (2021). Semi Truck Fenders Catalog. Minimizer. https://www.minimizer.com/productcategory/on-the-truck/fenders/

U.S. DOE. (2013). Roadmap and technical white papers. 21st Century Truck Partnership. https://www.energy.gov/sites/prod/files/2014/02/f8/21ctp_roadmap_white_papers_2013.pdf

U.S. DOE. (2021). U.S. Energy Information Administration (EIA). https://www.eia.gov/

U.S. DoT. (2013). Corporate average fuel economy (CAFE) standards. https://www.transportation.gov/mission/sustainability/corporate-average-fuel-economycafe-standards

U.S. EPA. (2020). Advancing sustainable materials management: 2018 fact sheet: Assessing 
trends in materials generation and management in the United States.

https://www.epa.gov/sites/production/files/2021-

01/documents/2018_ff_fact_sheet_dec_2020_fnl_508.pdf

U.S. EPA. (2021). Inventory of U.S. greenhouse gas emissions and sinks: 1990-2019. https://www.epa.gov/ghgemissions/inventory-us-greenhouse-gas-emissions-and-sinks

Volvo Group. (2021). Volvo trucks. Volvo. https:/www.volvotrucks.us/

W. W. Grainger Inc. (2021). Grainger industrial supply: MRO products, equipment and tools. Grainger. https://www.grainger.com/

Wolff, S., Seidenfus, M., Gordon, K., Álvarez, S., Kalt, S., \& Lienkamp, M. (2020). Scalable life-cycle inventory for heavy-duty vehicle production. Sustainability 2020, 12(13), 5,396. https://doi.org/10.3390/SU12135396

Woodbine Manufacturing Company Inc. (2018). Liftgate guide: The original Tommy Gate hydraulic lift. https://www.tommygate.com/media/528305/tg_2018-liftgateguide.pdf

Zhao, Y., Onat, N. C., Kucukvar, M., \& Tatari, O. (2016). Carbon and energy footprints of electric delivery trucks: A hybrid multi-regional input-output life cycle assessment. Transportation Research Part D: Transport and Environment, 47, 195-207. https://doi.org/10.1016/J.TRD.2016.05.014

Zhao, Y., \& Tatari, O. (2017). Carbon and energy footprints of refuse collection trucks: A hybrid life cycle evaluation. Sustainable Production and Consumption, 12, 180-192. https://doi.org/10.1016/J.SPC.2017.07.005

Zhou, T., Roorda, M. J., MacLean, H. L., \& Luk, J. (2017). Life cycle GHG emissions and lifetime costs of medium-duty diesel and battery electric trucks in Toronto, Canada. Transportation Research Part D: Transport and Environment, 55, 91-98. https://doi.org/10.1016/J.TRD.2017.06.019 



\section{Argonne $\mathbf{A}$}

\section{Energy Systems Division}

Argonne National Laboratory

9700 South Cass Avenue, Bldg. 362

Lemont, IL 60439-4854

www.anl.gov 